\title{
Capital Market Integration and Wages
}

\author{
Anusha Chari, Peter Blair Henry and Diego Sasson**
}

November 2011

\begin{abstract}
For three years after the typical emerging economy opens its stock market to inflows of foreign capital, the average annual growth rate of the real wage in the manufacturing sector increases by a factor of three. No such increase occurs in a control group of countries that do not liberalize. The temporary increase in the growth rate of the real wage drives up the level of average annual compensation for each worker in the sample by $\$ 487$ U.S.- an increase equal to nearly one-fifth of their annual pre-liberalization salary. The increase in the growth rate of labor productivity in the wake of liberalization exceeds the increase in the growth rate of the real wage so that the increase in workers' incomes does not drive up unit labor costs. Overall, the results suggest that trade in capital may have a larger impact on wages than trade in goods.
\end{abstract}

\footnotetext{
Correspondence to achari@unc.edu, pbhenry@nyu.edu and diego.sasson@gmail.com. Henry gratefully acknowledges financial support from the W.R. Berkley and Richard R. West Professorships, the John A. and Cynthia Fry Gunn Faculty Fellowship, the Stanford Institute for Economic Policy Research and the Stanford Center for International Development. Henry is a member of the Board of Directors of Kraft Foods and the National Bureau of Economic Research (NBER). Sasson is an employee of Goldman Sachs. We thank Sandile Hlatshwayo for excellent research assistance. We also thank Olivier Blanchard, Steve Buser, Brahima Coulibaly, Jonah Gelbach, Pierre-Olivier Gourinchas, Avner Greif, Nir Jaimovich, Pete Klenow, Anjini Kochar, John Pencavel, Paul Romer, Robert Solow, Ewart Thomas and seminar participants at UC Berkeley, Brookings, the Chicago Fed, Claremont McKenna, the IMF, MIT, NIPFP-DEA, the Reserve Bank of India, and Stanford for helpful comments. The views in this paper are our own and do not reflect those of Kraft, the NBER, or Goldman Sachs.
} 


\section{Introduction}

The impact of trade on wages occupies a salient space in the collective imagination of the economics profession. When a country opens up to trade with the rest of the world, income shifts away from that country's scarce factor of production and toward the one which is abundant (Stolper and Samuelson, 1941). Inspired by the celebrated Stolper-Samuelson Theorem, economics journals abound with articles examining the extent to which trade induces factor price equalization.

The evidence so far is mixed. The consensus view suggests that trade with developing countries is, at best, a modest force behind the large decline in the relative wages of low-skilled workers in rich countries (Krugman, 1995; Lawrence and Slaughter, 1993; Cline, 1997; Lawrence, 2008). ${ }^{1}$ In the case of workers in developing countries, the evidence actually runs contrary to the theory. Whereas Stolper-Samuelson predicts that trade with rich countries will increase the relative wages of low-skilled workers in poor countries, trade liberalization during the 1980s and 1990s actually increased wage inequality in the developing world (Goldberg and Pavcnik, 2007).

Moving from trade in goods to trade in factors, an extensive literature also exists on the impact of labor flows on wage inequality. Again, the results are mixed. Some studies find that immigration from developing countries exacerbates wage inequality in the U.S. (Borjas, Freeman and Katz, 1997). Others find little to no effect (Card, 2009; Ottaviano and Peri, 2008).

While many studies examine the impact of cross-border flows of goods and workers on relative wages, the literature pays far less attention to the impact of cross-border financial flows on the absolute level of wages. This is surprising for at least three reasons.

First, trade in capital between nations has implications for real wages that are every bit as important as cross-border movements of goods and people. In emerging economies where capital is scarce and labor abundant, opening up to free trade in capital should reduce the rental rate and increase the real wage.

Second, examining the absolute level of wages provides information about the impact of opening up on the distribution of income between capital and labor that is just as important as the information that studies of wage inequality provide about the distribution of labor income

\footnotetext{
${ }^{1}$ Feenstra and Hanson (2003) provide a dissenting view.
} 
between high and low-skilled workers. For instance, many emerging economies experienced unprecedented increases in national income as a result of globalization in the 1980s and 1990s. If all of the income gains from globalization accrued to capital, then the rise in wage inequality documented by Goldberg and Pavcnik (2007) necessarily implies that low-skilled workers experienced income losses. On the other hand, if total labor income grew in line with (or faster than) the economy as a whole, then high-skilled workers may have experienced income gains that did not result in losses for low-skilled workers.

Third, in the late 1980s emerging economies all over the world began easing restrictions on capital inflows of all kinds, giving economists a series of before-and-after scenarios with which to study the impact of factor flows on factor rewards. A large body of research examines the impact of capital market liberalization on asset prices, investment and the growth rate of GDP per capita. ${ }^{2}$ But to the best of our knowledge, this literature is silent about the impact of capital account opening on the labor market. Consequently, two decades after the onset of capital market liberalization, we still have no systematic evidence about the impact of this sea change in policy on the average level of wages in the developing world. ${ }^{3}$ This paper provides the first systematic attempt to fill that gap.

Figure 1 demonstrates that the level of the average annual manufacturing real wage in a sample of twenty-five emerging economies increased significantly after they liberalized restrictions on inflows of foreign capital between 1986 and $1996 .{ }^{4}$ Formal estimates show that the growth rate of the real wage in local currency terms jumped from 1.8 percent per year in the pre-liberalization period to an average of 5.7 percent in the year liberalization occurred and each of the subsequent three years. The 3.9 percentage-point increase in the growth rate of the real wage during this window drives up the level of average annual compensation for each worker in the sample of liberalizing countries by the local currency equivalent of $\$ 487$ U.S. - an increase equal to 18 percent of their annual pre-liberalization salary.

\section{[Insert Figure 1 Here]}

\footnotetext{
2 See Henry (2007) and Obstfeld (2009) for comprehensive surveys of this literature.

3 Feenstra and Hanson (1997) explore the cost of capital but focus on its impact on relative wages. Aitken, Harrison and Lipsey (1996), Almeida (2007), and Hale and Long (2008) examine FDI and wages, but not the general connection between financial flows and wages vis-à-vis the cost of capital.

${ }^{4}$ In order to have comparable measures of levels of wages across countries, we plot the natural log of the real wage in PPP adjusted \$U.S. terms.
} 
One concern about Figure 1 is that an exogenous worldwide shock unrelated to capital market opening drove up real wages in liberalizing and non-liberalizing countries alike. To distinguish the country-specific impact of liberalization policy from that of a common shock, our estimation procedure compares the difference in wage growth before and after liberalization for a group of countries that open up, to the same difference for a group of control countries. Our regressions also include year-fixed effects to account for the possibility of common shocks that affect only the liberalizers, and country-fixed effects to allow for differences in underlying unobservable factors that may drive variation in wage growth across countries. We also control for the impact of contemporaneous macroeconomic reforms such as inflation stabilization, trade liberalization, privatization and Brady Plan debt relief programs. In every specification, we find an economically and statistically significant increase in real wage growth for countries in the liberalization group relative to the control group.

An open economy interpretation of the neoclassical growth model provides the cleanest qualitative explanation of the new facts we uncover. Opening up to capital inflows reduces the cost of capital in developing countries, and firms respond by increasing their rate of investment. For a given growth rate of the labor force and total factor productivity, a higher rate of investment increases the ratio of capital per effective worker, driving up the marginal product of labor and, in turn, the market-clearing wage. Consistent with this chain of logic, Figure 2 demonstrates that the growth rate of labor productivity also rises sharply following liberalizations. After controlling for other factors, the average growth rate of labor productivity is 9.72 percentage points higher during the four-year liberalization window than it is in nonliberalization years.

\section{[Insert Figure 2 Here]}

From a quantitative perspective, however, it is less clear whether the neoclassical model captures all relevant features of the data. In the standard growth model, capital account liberalization works strictly through its impact on capital accumulation and has no effect on the growth rate of aggregate total factor productivity (Gourinchas and Jeanne, 2006). The increase in real wage growth present in the data is too large to be explained exclusively by capital deepening under conventional assumptions about capital shares and the elasticity of substitution. One possible explanation stems from the observation that liberalizations increase the quantity of 
capital goods that emerging economies import from industrial nations (Alfaro and Hammel, 2007). If technology diffuses from developed to emerging economies through the technology embodied in capital goods imports à la Eaton and Kortum (1999, 2001a, b), then liberalizations may indeed drive up the growth rate of total factor productivity.

While our approach enables us to test previously unexamined real-wage implications of capital market opening, difference-in-difference estimation requires caution because the standard errors are susceptible to serial correlation (Bertrand, Duflo, and Mullainathan, 2004). Opening up to foreign capital increases investment, which in turn drives up productivity and wages. Because wages take time to adjust, wage growth for a given country may remain elevated above its steady-state rate for a number of years after opening, thereby inducing serial correlation in the country's wage-growth residuals. Similarly, many countries open up at approximately the same time, possibly inducing cross-country correlation in the residuals. Our empirical analysis uses the Petersen (2009) technique to simultaneously adjust the standard errors for the potential presence of both types of correlation in the residuals. No matter how we compute the standard errors, the impact of capital market opening on wages and productivity remains economically and statistically significant.

The potential endogeneity of the liberalization decision also raises some concerns. If profit-maximizing firms in a financially closed economy face the prospect of rapidly rising labor costs, they will want to substitute capital for labor. To the extent that opening up the capital account would reduce the cost of capital, these firms have an incentive to lobby the government to do so. If rising wages cause governments to open up, then our estimates will spuriously indicate a strong impact of liberalization on wages, when causation in fact runs the other way around. While theoretically plausible, the endogeneity argument has no empirical support. Figure 1 is not consistent with the view that capital market opening occurs in response to rising labor costs. If anything, wage growth actually falls slightly prior to the opening (Section 4C shows that mean reversion à la Ashenfelter [1978] does not drive our results). The data are also not consistent with the explanation that governments liberalize in anticipation of higher future labor costs. Although wages rise sharply following liberalization, labor productivity rises even faster, so unit labor costs do not increase.

Finally, with only twenty-five countries in the sample, one may worry that a few large outliers drive the central finding. This is not the case. Sign tests show that the median growth 
rate of real wages in the post-liberalization period exceeds the pre-liberalization median too often to be explained by chance.

The rest of the paper proceeds as follows. Section II uses theory to generate testable predictions and explains how we identify real-life liberalization episodes. Section III describes the data and construction of the control group, and presents preliminary findings. Section IV discusses the empirical methodology, main results, and alternative interpretations. Section V examines the consistency of the results with the theory. Section VI concludes.

\section{Capital Market Integration in Emerging Economies}

This section uses an open economy version of the Solow model to generate previously untested predictions about the impact of capital flows on the time-path of the real wage $(w)$. The central theoretical point about capital market integration is that it moves emerging economies from a steady state in which their ratios of capital to effective labor are lower (and rates of return to capital higher) than in the industrialized world, toward a steady state in which ratios of capital to effective labor, and rates of return, are equal in both regions.

Because capital and labor are complements in production, the marginal product of labor (and hence the real wage) rises as countries open up and the process of capital deepening sets in. This fundamental insight about capital flows and the dynamic path of wages would also hold in an open economy Ramsey model. Since the focus of the paper is on wages, not other variables (e.g., the current account) that depend on endogenous savings decisions, the Solow model provides the most concise exposition.

\section{IIA. Theory}

Assume that a country produces output using capital, labor, and a constant-returns-toscale production function with labor-augmenting technological progress:

$$
Y=F(K, A L)
$$


Let $k=\frac{K}{A L}$ be the amount of capital per unit of effective labor and $y=\frac{Y}{A L}$ the amount of output per unit of effective labor. Using this notation and the homogeneity of the production function we have:

$$
y=f(k)
$$

Also assume that: the country saves a constant fraction of national income each period and adds it to the capital stock, capital depreciates at the rate $\delta$, the labor force grows at the rate $n$, and total factor productivity grows at the rate $g$.

When the economy is in steady state, $k$ is constant at the level $k_{s . s t a t e}$, and the marginal product of capital equals the interest rate $(r)$ plus the depreciation rate:

$$
f^{\prime}\left(k_{\text {s.state }}\right)=r+\delta \text {. }
$$

Because the impact of liberalization works through the cost of capital, Equation (3) has important implications for the dynamics of $k$ and $w$ in the wake of opening up.

Let $r^{*}$ denote the exogenously given world interest rate. The standard assumption in the literature is that $r^{*}$ is less than $r$, because the rest of the world has more capital per unit of effective labor than the developing country. It is also standard to assume that the developing country is small, so that nothing it does affects $r^{*}$. Under these assumptions, capital surges in to exploit the difference between $r^{*}$ and $r$ when the developing country liberalizes.

The absence of any frictions in the model means that the country's ratio of capital to effective labor jumps immediately from $k_{\text {s.state }}$ to its post-liberalization, steady-state level $\left(k_{s . s t a t e}^{*}\right)$. In the post-liberalization steady state, the marginal product of capital equals the world interest rate plus the rate of depreciation:

$$
f^{\prime}\left(k_{s . s t a t e}^{*}\right)=r^{*}+\delta \text {. }
$$


Instantaneous convergence implies that interest rates equalize immediately and that the country installs capital at the speed of light. Two remarks about this unattractive feature of the model are in order.

First, instantaneous capital market convergence is not an artifact of the Solow model, but of the small open economy assumption under which liberalization gives the country access to an infinitely elastic supply of capital at the world interest rate. The same counterfactual phenomenon would also occur in an open economy Ramsey model. Second, although we do not see equalization of interest rates and capital-labor ratios across countries in the real world, a large literature documents that the cost of capital drops and investment booms when developing countries remove barriers to capital inflows. ${ }^{5}$

There are a variety of formal methods for slowing down the speed of transition (e.g., adjustment costs of capital installation), but all of these methods would belabor the exposition without altering the model's fundamental prediction. ${ }^{6}$ The vital point is that $\dot{k}$ is greater than 0 during the country's transition to its post-liberalization steady state. The temporary growth in $k$ has important implications for the time path of real wage growth, which we now derive.

The growth rate of the real wage is the derivative of the natural $\log$ of $w$ with respect to time, that is, $\frac{\dot{w}}{w}=\frac{d}{d t}(\ln w(t))$. Since workers are paid their marginal product of labor, $w=A\left[f(k)-k f^{\prime}(k)\right]$. This means that the growth rate of the real wage is given by: $\frac{\dot{w}}{w}=\frac{d}{d t}\left(\ln (w(t))=\frac{d}{d t}\left\{A\left[f(k)-k f^{\prime}(k)\right]\right\}=\frac{\dot{A}}{A}-\frac{k f^{\prime \prime}(k) \dot{k}}{\left[f(k)-k f^{\prime}(k)\right]}\right.$. We may write this expression as:

$$
\frac{\dot{w}}{w}=\frac{\dot{A}}{A}+\frac{1}{\sigma} * \frac{f^{\prime}(k) k}{f(k)} * \frac{\dot{k}}{k}
$$

where $\sigma=-\frac{f^{\prime}(k)\left[f(k)-k f^{\prime}(k)\right]}{f(k) f^{\prime \prime}(k) k}$ is the elasticity of substitution.

\footnotetext{
${ }^{5}$ See Henry (2007), Stulz (2005) and the references therein.

${ }^{6}$ See Chapter 2 of Barro and Sala-I-Martin (1995) and Section 4.1 of Henry (2007).
} 
The right-hand side of Equation (5) demonstrates that the growth rate of the real wage depends on the sum of two terms. The first term, the growth rate of total factor productivity $\left(\frac{\dot{A}}{A}\right)$, is not affected by capital account policy in the canonical version of the neoclassical growth model. In Section $\mathrm{V}$ we discuss the implications of recent work that adopts a more catholic view of the relationship between capital account liberalization and total factor productivity. For now, we proceed as though the impact of liberalization works strictly through the second term, which is the product of the inverse of the elasticity of substitution $\left(\frac{1}{\sigma}\right)$, capital's share in national income $\left(\frac{f^{\prime}(k) k}{f(k)}\right)$, and the growth rate of the ratio of capital per unit of effective labor $\left(\frac{\dot{k}}{k}\right)$.

Prior to liberalization, the ratio of capital to effective labor is constant at the level $k_{\text {s.state }}$, so that $\frac{\dot{k}}{k}$ equals 0 , and $w$ simply grows at the same rate as total factor productivity. Since $\frac{\dot{k}}{k}$ is greater than 0 during the transition to $k_{s . s t a t e}^{*}$, the growth rate of the real wage also increases temporarily. Figure 3 illustrates the hypothetical time paths of $r$ and the natural $\operatorname{logs}$ of $k$ and $w$ under the assumption that the interest rate converges immediately upon liberalization but the ratio of capital to effective labor does not.

\section{[Insert Figure 3 Here]}

Again, previous work documents that the actual responses of the cost of capital and the quantity of capital to liberalization resemble their hypothetical time paths. Figure 1 demonstrates that the growth rate of the real wage also behaves in accordance with the theory. In Section V we examine whether the size of the real wage increase is consistent with the magnitude of the previously documented increases in the growth rate of capital. The next subsection explains how we identify the real-life liberalization episodes used to construct Figure 1.

\section{IIB. Reality}

An ideal test of the prediction that real wage growth will rise following the removal of restrictions on capital inflows requires information on capital account liberalization dates that is 
more precise than one can generally obtain. In theory, opening the capital account is as simple as pulling a single lever. In reality, the capital account has many components, so trying to determine exactly when a country liberalizes (as in Subsection IIA) is not a trivial task. In fact, the difficulty of determining precise liberalization dates causes most papers in the literature to ignore the problem (Eichengreen, 2001). Instead of asking whether opening the capital account has an impact on a country's growth rate (as theory clearly dictates), most published studies examine whether openness and long-run growth are positively correlated across countries. The distinction matters greatly. Testing for the effect of openness on growth can produce spurious results that tell us nothing about the true impact of liberalization (Henry, 2007).

In contrast to the previous literature which makes no attempt to find periods of opening, this paper identifies liberalization dates using the point in time when countries first permitted foreigners to purchase shares of companies listed on the domestic stock market. Relative to the most general conception of the capital account, at first blush the lifting of restrictions on foreign investment in the stock market may seem like a narrow way to define capital account liberalization. But deeper reflection reveals that stock market liberalizations serve as observable de facto indicators of harder-to-pinpoint de jure policy changes. ${ }^{7}$

For instance, the establishment by a foreign financial institution of an equity mutual fund is the modal means through which countries first liberalize their stock markets (see Table 1). If country-fund opening dates are valid proxies for the occurrence of broader, undocumented liberalizations that took place in the late 1980s and early 1990s, then significant quantities of capital that are not associated with any particular fund may flow in to the country as a consequence of the opening. Three facts suggest that our stock market liberalization dates provide non-specious indicators of a larger move toward open capital markets.

\section{[Insert Table 1 Here]}

First, a steady stream of country funds, issuances of American Depository Receipts, and other vehicles for foreign savers to buy domestic stocks typically follow the initial stock market liberalizations (Karolyi, 2004; Gozzi, Levine and Schmukler, 2010). As a case in point, Chile liberalized its stock market in May 1987 through the Toronto Trust Mutual Fund, a Canadian

${ }^{7}$ See Kose et al. (2006) for a detailed discussion of de facto versus de jure indicators. 
closed-end fund with a net asset value of $\$ 37.7$ million U.S. ${ }^{8}$ In the next five years, six additional country funds with a cumulative net asset value of $\$ 991.8$ million were established in Chile. ${ }^{9}$

Moving beyond Chile, Figure 4 demonstrates the extraordinary change wrought by stock market liberalizations in emerging economies. Net inflows of equity capital to the developing world, practically non-existent in the 1970s and early 1980s, accelerated sharply after the median stock market liberalization date in our sample (1989). Policy makers often raise concerns about the potential volatility of portfolio capital, worrying that net inflows of equity can easily turn to net outflows at the first sign of trouble. The facts do not substantiate this concern. While Figure 4 indicates that the pace of equity inflows to developing countries slowed following the Mexican Crisis in 1994-95 and the Asian Crisis of 1997-98, there is nothing that remotely resembles a reversal of equity inflows. ${ }^{10}$

\section{[Insert Figure 4 Here]}

It is also important to note that stock market liberalizations account for a substantial fraction of foreign direct investment (FDI), the most stable form of foreign capital. A common misconception views FDI solely as green field investment, where a foreign company builds from scratch a new manufacturing plant in an emerging economy. As a matter of official statistics, FDI includes any stock transaction (i.e., a cross-border merger or acquisition) that results in the purchaser owning 10 percent or more of the voting shares. ${ }^{11}$ In fact, from 1991-2000, crossborder mergers and acquisitions accounted for 48 percent of FDI in Latin America and 61 percent in East Asia (Chari, Ouimet, and Tesar, 2004).

Second, the facilitation of cross-border financial flows and ownership through stock market liberalization also induces large inflows of physical capital. Stock market liberalizations in emerging economies coincide with a significant increase in their imports of capital goods. In

\footnotetext{
8 See Park and Van Agtmael (1993), Price (1994), and Wilson (1992).

9 See Park and Van Agtmael (1993), Price (1994), and Wilson (1992).

${ }^{10}$ Concerns about the volatility of debt flows, on the other hand, are quite well founded. See Henry (2007) and Rogoff (1999).

11 The Organization of Economic Cooperation and Development (OECD) defines foreign direct investment (FDI) as: "A category of crossborder investment made by a resident in one economy (the direct investor) with the objective of establishing a lasting interest in an enterprise (the direct investment enterprise) that is resident in an economy other than that of the direct investor. The 'lasting interest' is evidenced when the direct investor owns at least $10 \%$ of the voting power of the direct investment enterprise" (OECD, 2008).
} 
a sample of twenty-five countries that liberalized their stock markets between 1980 and 1997 , liberalization led to a 9-percent increase in capital goods as a fraction of total imports, and the share of total machine imports to GDP rose by 13 percent (Alfaro and Hammel, 2007). Because developing countries do not produce a significant portion of the capital goods that they use, the observation that imports of capital goods rise in concert with the advent of portfolio equity inflows increases confidence in earlier work on liberalization and aggregate investment.

Third, with the sole exception of Malaysia during the Asian Crisis, none of the stock market liberalization dates from Table 1 were followed by a reversal of freedom of foreign access.

Taken together, these three facts confirm that stock market liberalizations signify the beginning of a steady march toward greater freedom of capital inflows and provide the closest empirical analogue to the textbook example in Subsection IIA. Accordingly, we use the stock market liberalization dates in Table 1 as the empirical counterpart to year [0] in the model of Subsection IIA (Figure 3). Standard and Poor's Emerging Markets Database covers 53 emerging economies with stock markets. Of these 53 countries, 25 have stock market liberalization dates that are: (a) consistently used elsewhere in the literature and (b) verifiable from primary sources. Column (1) of Table 1 lists these twenty-five countries and the year in which they liberalized. ${ }^{12}$ Table 2 presents summary statistics on the behavior of real wages in each of the twenty-five liberalizing countries. The next section explains the source and construction of the wage data.

[Insert Table 2 Here]

\section{Data}

The wage data come from the Industrial Statistics Database of the United Nations Industrial Development Organization (UNIDO). UNIDO provides data on total wages and salaries, total employment, and output for the manufacturing sector. For a given year, wages and salaries include all payments to employees in cash or in kind. Payments include: (a) direct wages and salaries; (b) remuneration for time not worked; (c) bonuses and gratuities; (d) housing allowances and family allowances paid directly by the employer; and (e) payments in kind.

${ }^{12}$ For further details about the complexities of determining liberalization dates see Section 5 of Henry (2007). 
Excluded from wages and salaries are employers' contributions on behalf of their employees to social security, pension, and insurance schemes, as well as the benefits received by employees under these schemes and severance and termination pay.

Conceptually, total wages and salaries equal $W^{*} L^{*} H$, where $W$ is the hourly wage rate, $L$ is the stock of labor and $H$ is total hours worked for the year. Since UNIDO provides no data on the number of hours worked or the hourly wage, we divide total wages and salaries by total employment $(L)$ to compute the average annual wage $\left(W^{*} H\right)$ of each worker in the manufacturing sector of each country (more on this point in Subsection IIIB.1). UNIDO reports the value of wages and salaries in local currency terms. We deflate each country's nominal annual wage in local currency by the local consumer price index (CPI) to create a local currencydenominated real wage.

In addition to information on wages, employment, and output, we would like to have data on the manufacturing capital stock. Unfortunately, UNIDO only provides data on investment. The standard approach to an absence of capital stock data converts investment flows to capital stocks with the perpetual inventory method by making assumptions about the initial level of capital in a given year and using the investment flows to interpolate the subsequent time path of the capital stock.

Interpolation is methodologically sound when the focus is on long-run relationships where assumptions about the initial stock of capital make little difference. In contrast, this paper focuses on short-run dynamics and therefore requires a clear picture of the trajectory of the capital stock during the liberalization window. Simply put, it would be inappropriate to interpolate the growth rate of the capital stock during liberalization episodes when trying to measure the impact of liberalization on capital stock growth. Moreover, the UNIDO data set is missing more than 50 percent of the country-year observations for investment in the aggregate manufacturing sector, and many of these missing observations fall within the liberalization window. In the absence of reliable capital stock data, we will use (in Section V) estimates of capital stock growth from previously published work to check the consistency of our results with the theoretical channel from capital growth to wages.

For each country in our sample, the annual wage data generally run from 1960 to 2003, with the exact dates differing by country. After taking the difference of the natural log to compute growth rates, we have a total of 758 country-year observations with which to identify 
the impact of liberalization on real wage growth. Table 1 shows that the timing of liberalizations is correlated across countries, so these 758 observations are not independent. For instance, liberalizations may coincide with an exogenous global productivity shock that drives up wages in all countries, irrespective of whether or not they liberalize.

To address whether it is the case that an exogenous shock unrelated to opening up drives the temporary increase in real wage growth, we select a group of control countries. The control group consists of developing countries that are similar to the liberalizing countries except that the control countries did not open their stock markets to foreign investment. Appendix A provides a list of countries that have stock markets but never liberalized. These nations comprise the control group against which we compare the real wage growth of the countries in our treatment group.

\section{IIIA. Descriptive Findings and Data Concerns}

Figure 1 exhibits a steep positive inflection after year [0], indicating a sharp increase in the growth rate of the real wage. However, with only twenty-five countries in the sample, an important question is whether a few outliers drive the increase.

The descriptive statistics in Table 2 suggest that this is not the case. Only four countries-Indonesia, Malaysia, Pakistan, and Thailand-have mean growth rates in the aftermath of liberalization that do not exceed their full sample mean (column 2). Turning from means to medians, for each country in the sample we also performed simple Wilcoxon signedrank tests on the data for each country (Wilcoxon, 1945). The procedure tests the equality of matched pairs of observations by using the Wilcoxon matched-pairs signed-ranks test. Applied to the current context, the null hypothesis is that the distributions of pre- and post-liberalization wage growth are the same. In the three-year post-liberalization period, five countries experience median real wage growth that falls below the median growth rate of their real wage in the preliberalization period. Given the null hypothesis, the probability (p-value) of finding no more than five countries with wage growth rates below their pre-liberalization median is 0.0015 .

Table 2 (Panel A) also shows the following quantities: (a) for each country, Column 1 gives the change in the natural log of the wage over the liberalization window (years [0] to [3]); we denote this variable "liberalization log wage change" as a convenient shorthand expression; (b) Column 2 gives the liberalization log wage change for each country expressed relative to the country's mean log wage change over the pre-liberalization window (years [-3] to [-1]); (c) 
Column 3 gives the liberalization log wage change for each country expressed relative to the contemporaneous mean log wage change for the control group over the liberalization window (years [0] to [3]); (d) Column 4 gives the difference-in-difference that results from subtracting the real log wage change for the treatment countries expressed relative to the control group in the pre-liberalization window from the quantity in Column 3.

The average cumulative log wage change for the treatment group during the liberalization window is $15.8 \%$ (Column 1); Relative to the pre-liberalization window, the cumulative log wage change is $19.1 \%$ (Column 2). Relative to the control group during the liberalization window, the cumulative log wage change is $26 \%$ (Column 3). The average difference-indifference of the cumulative log wage change is $20.2 \%$ (Column 4).

For each of the quantities in Columns 1-4, we test whether the mean differs significantly from zero and report a heteroscedasticity-consistent estimate of the standard error in Table 2, Panel B. These simple tests support the observation that liberalization leads to large effects on the level of real wages, lending credence to the more sophisticated regression results that follow.

To provide additional descriptive evidence, Table 3 presents estimates of the impact of liberalization on the growth rate of real wages over time. Panel A of Table 3 presents estimates of one coefficient only, but allowing progressively more periods after the reform (from year [2] up to [5]). For example, the coefficient on the variable DUMMYO3 estimates the average effect of liberalization on real wage growth in years [0], [1], [2], and [3]. The coefficient estimate of 0.0369 suggests that the average real wage growth in that four-year span is $3.69 \%$ per year, or an overall increase of 14.76 percentage points $(3.69 * 4)$. The average estimated effect of liberalization on wage growth differs between specifications. Consistent with the theoretical prediction that liberalization will produce a temporary increase in wage growth, the average effect becomes progressively smaller as we add more years subsequent to the liberalization window. We also estimated the coefficient estimates on the liberalization dummy over the [0,2], $[2,4]$, and $[4,6]$ event windows. However, the interpretation of the statistical difference of the coefficients across the different windows is difficult given their overlapping nature.

[Insert Table 3 Here] 
Panel A also presents an estimate of the "Ashenfelter" dip. The variable "Dummy ([-3], [-1]), "which takes on a value of one for the three years before liberalization, shows that the prereform dip in wage growth which is $-2.37 \%$ compared to the post-reform average real wage growth of $3.69 \%$ in the four years following liberalization.

Panel B presents the coefficient estimates on the liberalization dummy by individual year, ranging from the liberalization year [0] up to five years following the liberalization [5]. Columns 2 and 3 indicate that the impact of liberalization on real wages is positive and significant in both the first [1] and second [2] years following the liberalization. The coefficient estimates on the liberalization dummy are not significant in years [3] to [5]. The estimates in years [1] and [2] are significantly different from the coefficients in the other years.

Although the numbers in Tables 2 and 3 suggest a reasonably consistent increase in real wage growth across countries, two other questions about the data remain.

IIIA.1 Hours Worked. - First, the necessity of using annual data instead of hourly wages raises a potential measurement concern. If the average number of annual hours worked per employee increases following liberalizations then total annual compensation may rise without any change in the implied hourly wage. In other words, the rise in average annual labor income $\left(W^{*} H\right)$ documented in Figure 1 could be the result of an increase in hours worked rather than an increase in the hourly wage rate. To interpret the impact of liberalization on total annual compensation as an increase in labor's compensation per unit of time, we need to know that the average number of hours worked does not rise significantly following liberalizations.

In an attempt to address this concern we ran into non-trivial constraints that forced us to rely on data for a subset of the countries in our sample. UNIDO does not provide information on hours worked. Data available from the International Labor Organization (ILO) is also not helpful because the ILO's definition of hours worked is inconsistent across countries. Within a given country, the ILO's definition of hours worked sometimes varies across sectors and over time as well. In the end, we used data provided by the Groningen Growth and Development Center (GGDC) because GGDC seemed to take most seriously the problems associated with trying to construct a consistent cross-country measure of hours worked. In their own words, the GGDC's estimates of hours worked are based on “.... country-by-country...judgment of which sources made the most appropriate adjustments to achieve the preferred concept of actual hours 
worked per person employed" (GGDC, 2011). The GGDC data include paid overtime and exclude paid hours that are not worked due to sickness, vacation, and holidays.

Specifically, the data on hours worked come from GGDC's Total Economy Database, which extends the work of Angus Maddison (1980). Although the Total Economy Database contains annual numbers on GDP, population, employment, hours, and productivity for about 125 countries from 1950 to 2008, the series on hours worked per person are available for only 43 countries. Twelve of those 43 countries are also in our dataset: Argentina, Brazil, Chile, Colombia, Greece, Korea, Mexico, Portugal, Spain, Turkey, Taiwan, and Venezuela.

To assess whether the rise in average annual compensation is driven by an increase in hours worked, Figure 5, which plots the natural log of hours worked in liberalization time, illustrates that hours worked are invariant to liberalization. Between years [-5] and [-1] the average natural $\log$ of hours worked is 7.64. In years [1] through [5] the average is 7.62. In levels, these numbers translate to an average of 2,094 hours worked per year prior to liberalization and 2066 hours worked per year after. Dividing 2,094 and 2,066 by the number of weeks in a year (52, not adjusting for vacation time) gives an estimate of roughly 40 hours to the average work week in these twelve countries before and after opening up. That number seems entirely reasonable and reinforces our confidence in the GGDC data. Looking at medians instead of means does not alter the story. The median natural log of hours worked before liberalization is 7.59. The median after liberalization is also 7.59. In short, the number of hours worked per year does not change with liberalization and does not drive the increase in real wage growth documented in Figure 1. ${ }^{13}$

\section{[Insert Figure 5 Here]}

IIIA.2 Concurrent Economic Events. - A second concern is that capital market openings may coincide with major economic events that could have a significant impact on wages, independent of any effects of liberalization. Union activity provides a case in point. If agitation for higher pay by organized labor coincides with liberalization then the estimates may be overstated. A survey of labor market events during capital account liberalization episodes revealed that

\footnotetext{
13 As a final check we also used the GGDC data to construct a measure of hourly wages for the subset of twelve countries. Regressing the change in the natural log of the hourly wage on the same right-hand-side variables that appear in Equation (6), we find results that are qualitatively identical to those reported in Panel A of Tables 4 through 6.
} 
significant union activity to secure higher wages was present in only three of the twenty-five countries in our sample-Brazil, Turkey, and South Korea. When these countries are dropped, the cumulative raw difference-in-difference estimate is not substantively changed at $17.39 \%$. Also, when we control for unionization in the formal regression analysis, the coefficient on the capital account liberalization dummy remains unchanged. In two other countries-Chile and South Africa - the government thwarted protestors demanding wage hikes. The remaining 20 countries in the sample did not experience any significant union activity during their liberalization episodes.

While union activity does not drive the increase in wages, a separate concern is that liberalizations often coincide with major economic reforms that could have a significant impact on wages apart from any effects of liberalization. Stabilizing inflation, removing trade restrictions, and privatizing state-owned enterprises are all reforms that may affect real wages through their impact on the efficiency of domestic production. Indeed, Table 1 demonstrates that the timing of these reforms makes it plausible that they, not capital account liberalization, are responsible for the increase in real wages apparent in Figure 1. The next section, which presents our formal empirical methodology and results, uses the information in Table 1 to control directly for the impact of other reforms and to address a host of lingering concerns and alternative explanations.

\section{Empirical Methodology and Results}

We evaluate the statistical significance of the temporary increase in wage growth by estimating the following difference-in-difference panel regression specification:

$$
\begin{aligned}
& \Delta \ln w_{i t}^{\text {dif }}=a_{0}+\operatorname{COUNTRY}_{i}+a_{1} * \operatorname{LIBERALIZE}_{i t}+a_{2} * \operatorname{TRADE}_{i t}+a_{3} * \operatorname{STABILIZE}_{i t} \\
& +a_{4} * \text { PRIVATIZE } \\
& \text { it }
\end{aligned}
$$

The left-hand-side variable, $\Delta \ln w_{i t}^{\text {dif }}$, is the change in the natural log of the real local currency value of annual compensation for country $i$ in year $t$ minus the average change in the natural $\log$ of the real wage for the group of control countries in year $t$. Moving to the right-hand side of Equation (6), the variable LIBERALIZE ${ }_{i t}$ is a dummy variable that takes on a value of 1 in 
the year that country $i$ liberalizes ([0]) and each of the subsequent three years ([1], [2] and [3]). This means that the coefficient $a_{1}$ measures the average annual deviation of the growth rate of the real wage in the treatment group from the growth rate of the real wage in the control group during the three-year liberalization episode.

The right-hand side of Equation (6) also contains four additional country-specific dummy variables-STABILIZE, TRADE, PRIVATIZE, and BRADY - that are designed to prevent country-specific shocks in the shape of economic reforms from artificially inflating the coefficient on LIBERALIZE. We treat reforms and liberalization symmetrically, constructing dummy variables that take on the value 1 in the year a reform program begins and each of the three subsequent years.

Turning at last to the error term, $\varepsilon_{i t}$, it is important to note that when the residuals are correlated across observations, OLS standard errors can be biased and may over- or underestimate the true variability of the coefficient estimates. Specifically, the standard distributional assumptions needed for valid statistical inference will not hold in the presence of: (a) correlation of the residuals across countries within a given time period (cross-sectional dependence), or (b) correlation of the residuals within a given country over time (time-series dependence). Point (a) matters because liberalizations often occur at the same time for different countries, possibly inducing correlation in the wage-growth residuals across countries at a given point in time. Point (b) matters because it takes time for wages to adjust to their new trajectory; for a given country, wage growth may remain elevated above its steady-state rate for a number of years in the post-liberalization period, thereby inducing serial correlation in the country's wagegrowth residuals. To compute accurate standard errors we employ various clustering procedures described below.

\section{IVA. Benchmark Estimates: A Difference-in-Difference Specification}

Table 4 (Column 1) presents the results from our estimate of Equation (6), restricting the sample to data three years before the liberalization and three years after. We cluster the standard errors by year to account for potential cross-country correlation in the wage growth residuals. Column (1) of Table 4 shows that after accounting for the effects of inflation stabilization, trade 
liberalization, the Brady Plan, and privatization, the coefficient on LIBERALIZE is 0.031 . This implies that relative to the control group, the average growth rate of the typical country's real wage exceeds its long-run mean by 3.1 percentage points per year during liberalization episodes.

\section{[ Insert Table 4 Here]}

The impact of other economic reforms on the growth rate of the real wage is not as robust as that of liberalization, but we do find some significant effects of inflation stabilization and privatization when the regression specification includes these variables individually. ${ }^{14}$ The coefficient estimates demonstrate that controlling for the other economic reforms that tend to accompany liberalization does not reduce the impact of capital account opening on the growth rate of the real wage. This reinforces our confidence in the accuracy of the reform dates and the relevance of the corresponding dummy variables as controls.

Column 2 of Table 4 estimates Equation (6) using data that spans the entire sample to show that the impact of liberalization on real wage growth is robust to potential concerns about the length of the pre-liberalization window used for estimation. The coefficient on LIBERALIZE is 0.036 and is significant at the 1 percent level.

Turning from economic reforms to statistical issues, researchers do not always know whether the precise form of the dependence in residuals is time-series or cross-sectional in nature. As a way of addressing this concern, Petersen (2009) suggests a less parametric estimation approach that clusters on two dimensions simultaneously (e.g., country and time). Petersen's approach uses the following estimate of the variance-covariance matrix, which combines the standard errors clustered by country with the standard errors clustered by time: $V_{\text {Country\&Time }}=V_{\text {Country }}+V_{\text {Time }}-V_{\text {White }} \cdot{ }^{15}$

The first matrix on the right-hand side allows standard errors to be clustered by country, capturing the unspecified correlation between observations on the same country in different years (e.g., correlations between $\varepsilon_{\mathrm{it}}$ and $\varepsilon_{\mathrm{is}}$ ). The second matrix on the right-hand side, allows standard

\footnotetext{
14 The estimate of the coefficient on the liberalization dummy ranges 0.031 to 0.043 and is statistically significant at the 1 percent level in nearly every specification that includes the economic reform dummies one by one. These additional results are available in an online appendix on the journal's website.

15 Proposed by Cameron, Gelbach, and Miller (2006), and Thompson (2006).
} 
errors to be clustered by time, capturing the unspecified correlation between observations on different countries in the same year (e.g., correlations between $\varepsilon_{\mathrm{it}}$ and $\varepsilon_{\mathrm{kt}}$ ). Since both the country- and time-clustered variance-covariance matrices include the diagonal of the variancecovariance matrix, the Petersen procedure subtracts off the White variance-covariance matrix to avoid double counting. This method allows for both a country and a time effect, although observations on different countries in different years are assumed to be uncorrelated. Petersen (2009) demonstrates through simulation that clustering by two dimensions produces less biased standard errors.

Table 4 (Columns 3 and 4) presents estimates of Equation (6) that use Petersen's (2009) procedure to simultaneously cluster the standard errors by year (to adjust for cross-country correlation) and by country (to adjust for serial correlation). ${ }^{16}$ Since it is not possible to include country-fixed effects while simultaneously clustering the standard errors by year and country, the magnitudes of the estimates in Columns 3 and 4 are not identical to those in Columns 1 and 2, but they are very similar. Focusing, then, on the precision of the estimates, we see that the coefficient estimate on LIBERALIZE (in Columns 3 and 4) is significant at the 5 and 1 percent confidence levels, respectively. This suggests that our general finding is robust to concerns about both serial and cross-country correlation in the error terms.

IVA.1 An Alternative Specification: Country and Year Fixed Effects.- As an alternative to our difference-in-difference estimates, we regress the change in the natural log of the real wage or a full set of country-fixed and year-fixed effects plus the reform dummies. Specifically, we estimate:

$$
\begin{aligned}
& \Delta \ln w_{i t}=a_{0}+\operatorname{COUNTRY}_{i}+\text { YEAR }_{t}+a_{1} * \operatorname{LIBERALIZE~}_{i t}+a_{2} * \operatorname{TRADE}_{i t}+ \\
& a_{3} * \operatorname{STABILIZE}_{i t}+a_{4} * \operatorname{PRIVATIZE}_{i t}+a_{5} * \operatorname{BRADY}_{i t}+\varepsilon_{i t}
\end{aligned}
$$

The left-hand-side variable, $\Delta \ln w_{i t}$, is the natural $\log$ of the real local currency value of annual compensation for country $i$ in the treatment group in year $t$ minus the same variable in year $t-1$. The variable $Y E A R_{t}$ is shorthand for the set of year-fixed effects. The right-hand side of

${ }^{16}$ For another discussion of multi-way clustering see Cameron, Gelbach, and Miller (2009). 
Equation (7) also contains four additional dummy variables-STABILIZE, TRADE, PRIVATIZE, and $B R A D Y$. The standard errors are clustered by year.

Table 4 (Column 5) presents the results from our estimate of Equation (7). The standard errors are clustered by year to account for potential cross-country correlation in the wage growth residuals. The impact of liberalization on real wage growth is economically large. Controlling for the effects of inflation stabilization, trade liberalization, the Brady Plan, and privatization, the coefficient on LIBERALIZE is 0.0388 and significant at the 5 percent level. ${ }^{17}$ This means that during liberalization episodes, the average growth rate of the typical country's real wage exceeds its long-run mean by 3.88 percentage points per year. Accounting for the other economic reforms that tend to accompany liberalization also does not affect the impact of capital account opening on the growth rate of the real wage.

\section{IVB. Alternative Explanations}

One interpretation of the evidence says that wages rise following liberalizations because of an increase in labor demand stemming from a capital-deepening induced rise in productivity. Alternatively, the increase in wages may be due to a reduction in labor supply. The argument runs as follows. If workers perceive the impact of liberalization on wages to be permanent, then they effectively receive a positive shock to their permanent income and may reduce their labor supply accordingly. If this is the case then the observed increase in wage growth may stem from a decrease in labor supply as well as an increase in labor demand. ${ }^{18}$

The employment data are not consistent with a decrease in labor supply. There is no discernible change in the growth rate of employment following liberalizations. The regression specifications in Table 5 examine the change in the natural log of employment on the same righthand-side variables that appear in Equation (7). The liberalization dummy is never significant. Also, if labor supply decreases then we would also expect a decline in the number of hours worked. Again, Figure 4 demonstrates that this is not the case. Overall, the evidence does not suggest that workers reduce their labor supply in response to liberalization. While we do not

\footnotetext{
17 The estimate of the coefficient on LIBERALIZE ranges from 0.038 to 0.043 in additional regressions that include the reform dummies individually. The coefficients on the liberalization dummy are statistically significant at the 1 percent level. These results are available in an online appendix on the journal's website.

An alternative view is that labor supply is relatively inelastic (see Pencavel 1986 on this point). If this is the case, workers may not reduce the number of hours that they want to work in response to the increase in their expected future income.
} 
formally estimate the labor supply decision and cannot exclude the possibility that part of the wage increase results from a decrease in labor supply, if this alternative explanation is at work its overall impact appears to be second order.

[Insert Table 5 Here]

\section{IVC. Economic Interpretation}

There are two ways to examine the economic significance of the results. First, consider the magnitude of the growth rate of the real wage during liberalization episodes relative to the growth rate of the real wage over the entire sample. To do this, use the estimate of the constant and the liberalization dummy from the regression that controls for other economic reforms (Column 5 in Table 4). Real wages grow by an average of 1.8 percent per year over the entire pre-liberalization sample. The estimate of the coefficient on the liberalization dummy is 0.039 . Adding the average pre-liberalization real wage growth to the coefficient on the liberalization dummy gives the average growth rate of the real wage during liberalization episodes -5.7 percent per year. This means that in the year the liberalization occurs and each of the subsequent three, the average growth rate of the real wage is almost three times as large as in nonliberalization years (5.7 versus 1.8$)$.

Of course, the increase in the growth rate of the real wage is temporary, so a second way of assessing economic significance is to compute the impact of liberalization on the permanent level of the real wage. For the countries in the treatment group, the average level of annual compensation in the year before liberalization (year [-1]) is 2,686 PPP-adjusted dollars. During the three-year liberalization window the real wage grows at 5.7 percent per year, so that by the end of year [3] the average level of the real wage is $2,686 e^{0.057 * 4}=3,374$ PPP-adjusted dollars. Now assume that in the absence of liberalization the real wage would have grown at the sample mean of 1.8 percent per year. In that case, the level of the real wage at the end of year [3] would be $2,686 e^{0.018^{*}}=2,887$ PPP-adjusted dollars. In other words, by the time the impact of liberalization has run its course, the average worker in the manufacturing sector has annual takehome pay that is 487 dollars higher $(3,374$ minus 2,887$)$ than it would have been in the absence of liberalization. This change in the level of the wage is equal to nearly one-fifth of the average manufacturing worker's pre-liberalization, PPP-adjusted take-home pay. 
It is also important to note that the results are not an artifact of mean reversion following a temporary fall in earnings à la Ashenfelter (1978). Figure 1 shows a decline in the level of the real wage from an average of 2,968 PPP-adjusted dollars five years prior to liberalization to an average of 2,686 PPP-adjusted dollars one year prior to liberalization. A few hypothetical calculations demonstrate that the results do not simply reflect a bounce-back effect. Suppose that instead of declining, on average, for the next four years (as they do in the data), real wages grew at their (continuously compounded) long-run rate of 1.8 percent per year over the preliberalization window. Under that scenario, the real wage in year [3] would have been 3,485 PPP-adjusted dollars. The actual level of the average real wage in year [3] is 4,050 PPP-adjusted dollars, roughly 20 percent higher than the level that would have prevailed had wages simply continued to grow at their long-run rate.

\section{IVD. The Impact of Liberalization on Productivity}

The results suggest that the response of wages to capital account liberalization is large. To scrutinize the plausibility of our estimates we cross-checked the results against data on labor productivity. The model in Section 2 demonstrates that liberalization induces capital deepening, and through the increase in capital per worker, drives up productivity, the demand for labor, and the real wage. If this chain of reasoning has any empirical bite, then, during liberalization episodes, labor productivity should rise in concert with wages.

To formally test the relation between liberalization and the growth rate of labor productivity, we estimate the following difference-in-difference regression:

$$
\begin{aligned}
& \Delta \ln \left(\frac{Y}{L}\right)_{i t}^{d i f}=a_{0}+\text { COUNTRY }_{i}+a_{1} * \text { LIBERALIZE }_{i t}+a_{2} * \text { TRADE }_{i t}+a_{3} * \text { STABILIZE }_{i t} \\
& +a_{4} * \text { PRIVATIZE } \\
& i t
\end{aligned}
$$

Equation (8) is identical to (6) except that instead of the change in the natural log of the annual wage, the left-hand-side variable is now the change in the natural log of the annual real value-added per worker in local currency terms minus the average change in the natural log of real value-added per worker in the control group. Again, to be consistent with the wage estimates, we cluster the standard errors by year. 
Table 4 (Column 6) shows that liberalization has a positive and significant impact on productivity growth. Accounting for the potential impact of other economic reforms, the estimate of the coefficient on the liberalization dummy is 0.0972 when the sample is restricted to the three years prior to and three years following the liberalization year. ${ }^{19}$ This means that the average growth rate of productivity is 9.72 percentage points higher during the three-year liberalization window than in non-liberalization years. The 9.72 percentage point increase in productivity growth associated with liberalization is larger than the 3.9 percentage point increase in wage growth. Because the increase in productivity outstrips the increase in wage growth, manufacturing-sector profitability actually rises during liberalizations. ${ }^{20}$ Column 7 of Table 4 shows that the results for productivity growth and liberalization are robust to all of the statistical concerns raised about the estimation of wage growth and liberalization examined in Subsection IVA.

\section{Discussion}

While the size of the increase in productivity growth more than matches the size of the increase in real wage growth, the important unanswered question is whether the magnitude of either increase is consistent with the model that drives the estimates. To answer the question, begin with the standard assumption that liberalization has no impact on total factor prodcutivity growth and recall Equation (5): $\frac{\dot{w}}{w}=\frac{\dot{A}}{A}+\frac{1}{\sigma} * \frac{f^{\prime}(k) k}{k} * \frac{\dot{k}}{k}$. With no change in the growth rate of total factor productivity, Equation (5) implies that the change in the growth rate of the real wage equals the product of three numbers: the reciprocal of the elasticity of substitution, capital's share in national income, and the change in the growth rate of capital per effective worker.

Specifically, we have:

$$
\frac{w}{w}=\frac{1}{\sigma} * \frac{f^{\prime}(k) k}{k} * \frac{\dot{k}}{k}
$$

\footnotetext{
${ }^{19}$ In the online appendix, every estimate of the coefficient on the liberalization dummy is statistically significant in regression specifications that include the reform dummies individually. These results suggest that liberalization, not an external shock or domestic economic reforms, is responsible for the increase in productivity growth.

20 Chari and Henry (2008) also find that the return to capital in the manufacturing sector rises during liberalizations.
} 
The capital share typically lies between $1 / 3$ and $1 / 2 .^{21}$ Obtaining an estimate of the change in capital growth requires a little more effort. We know from previous work that aggregate capital stock growth increases by 1.1 percentage points following liberalizations (Henry, 2003). We can use the aggregate number to calculate a rough upper bound for the change in manufacturing sector capital growth. For the countries in our sample, the manufacturing sector accounts for about 1/5 of GDP. Assuming zero net growth in capital for the agriculture and service sectors, the largest possible increase in the growth rate of capital in manufacturing is about 5.5 percentage points. This back-of-the-envelope calculation finds empirical support elsewhere in the literature. Using a subset of the countries in this paper, Chari and Henry (2008) calculate that the growth rate of capital in the manufacturing sector increases by 4.1 percentage points per year following liberalizations. Increases in capital stock growth between 4.1 and 5.5 percentage points are also consistent with the size of the fall in the cost of capital that occurs following liberalizations. $^{22}$

Suppose the capital share is $1 / 2$ and the change in capital growth is 5.5 percentage points. Then for capital-deepening alone to explain the 3.9 percentage-point increase in wage growth you need an elasticity of substitution less than or equal to 0.7 . If the capital share is $1 / 3$ and the change in capital growth is 4.1 percentage points, then the elasticity of substitution must be less than or equal to 0.35 . There is little consensus on the size of the elasticity of substitution. Early work estimated small elasticities that were statistically indistinguishable from zero. ${ }^{23}$ More recent studies cannot reject the hypothesis that the elasticity of substitution is 1 (Caballero, 1994). Most relevant to the countries in this paper, Coulibaly and Millar (2007) estimate an elasticity of substitution of about 0.8 for South Africa. With a standard error of 0.08 , the Coulibaly and Millar estimate could imply an elasticity as small as 0.64. With a change in capital growth of 5.5 percentage points, a capital share of $1 / 2$, and an elasticity of substitution of 0.64 , Equation (9) predicts that liberalization would generate a 4.3 percentage-point increase in wage growth.

\footnotetext{
21 A few studies find capital shares in developing countries as high as two-thirds (See for example, Rodríguez and Ortega, 2006). On the other hand, Gollin (2002) documents capital shares closer to a third.

22 See Henry (2007), pp. 897-900.

23 For a survey of this literature see Chirinko (1993).
} 
We do not mean to push any particular value for the capital share. And it is not clear that we have a consensus estimate of the size of the elasticity of substitution in developed countries, let alone emerging economies. What is clear, however, is that if you want to maintain the assumption that liberalization has no impact on total factor productivity, then the observed increases in wage growth are consistent with the model only if you are willing to concede that the elasticity of substitution is substantially less than 1 (i.e., the world is not Cobb-Douglas). But if the elasticity of substitution is significantly less than one, then it is hard to understand how capital's income share remains constant (or increases) following the liberalization-induced fall in the cost of capital.

On the other hand, if you maintain that the world is Cobb-Douglas, then our wage results imply that liberalization has an impact on total factor productivity. In a Cobb-Douglas world with a capital share of one half, Equation (9) implies an increase in real wage growth of 2.75 percentage points-leaving a gap of roughly 1 percentage point to be explained. A gap of 1 percentage point per year would require a 4 percent increase in the level of factor productivity over four years. If opening up brings about changes that raise an economy's permanent level of efficiency by four percent, then this will show up as a temporary increase in total factor productivity growth during the transition. ${ }^{24}$ One can imagine a number of channels that lie outside the confines of the Solow model through which liberalization raises efficiency by this magnitude over the course of a four year window.

For instance, liberalization may enable firms to import more efficient machines (e.g., tractors instead of hoes) that effectively shift the country's production technology closer to the world frontier. DeLong (2004) argues that after liberalizing the capital account "...developing countries...would enjoy the benefits from technology advances and from learning-by-doing using modern machinery." In other words, to the extent that technological progress diffuses from developed to developing countries, the importation of new machinery provides an important conduit through which the diffusion may occur (Eaton and Kortum, 2001a). Almost all of the world's research and development (R\&D) takes place in a small number of industrial countries (Eaton and Kortum, 1999), and the same group of countries accounts for over 70

\footnotetext{
24 While endogenous growth models such as Romer (1986) certainly allow for the possibility of permanent growth effects due to innovation, this view of the world strikes us as most relevant for countries that actually do the innovating. Emerging economies are more likely to be adopters of technology, engaged in a periodic process of capital upgrading and technological catch up that bears closer resemblance to periodic jumps in the level of total factor productivity.
} 
percent of the world's machine exports in a given year (Eaton and Kortum, 2001b; Alfaro and Hammel, 2007).

Evidence from the literature supports the conjecture that developing countries can import technological progress by liberalizing the capital account. In the immediate wake of liberalizations, firms in the manufacturing sector of developing countries accumulate capital at a faster rate than they did before the liberalization (Chari and Henry, 2008). Furthermore, these countries raise their rate of capital accumulation by importing more capital goods. As a result of liberalization, the share of capital goods imports to total imports rises by 9 percent, and the share of total machine imports as a fraction of GDP rises by 13 percent (Alfaro and Hammel, 2007).

The observation that both imports of capital goods and total factor productivity rise in concert with liberalization lends credence to the notion that new capital goods embody technological progress and that developing countries can raise their growth rates of total factor productivity by liberalizing the capital account. ${ }^{25}$ The observation is also consistent with work showing that cross-country variation in the composition of capital investment explains much of the cross-country variation in total factor productivity (Caselli and Wilson, 2003).

On the other hand, some argue that the simplest explanation of capital-accountliberalization-induced total factor productivity growth lies with the economic reforms that accompany liberalization. Economic reforms improve resource allocation, essentially producing a one-time shift in the production function that temporarily raises the growth rate of total factor productivity, without inducing technological progress per se (Henry, 2003). Others posit that liberalization facilitates increased risk sharing, which might encourage investment in riskier, higher-growth technologies (Levine, 1997; Levine and Zervos, 1998a). Yet another explanation is that capital account liberalization generates unspecified "collateral benefits" that increase productivity (Kose, Prasad, Rogoff, and Wei, 2006).

Sorting through competing explanations for the increase in total factor productivity following liberalizations is an important research challenge that lies beyond the scope of this paper. The bottom line of the discussion here is that the size of the increases in wage growth and productivity we report are consistent with the model that drives our estimation. Whether the primary source of those increases lies with capital deepening or increased total factor

\footnotetext{
${ }^{25}$ Also, in the spirit of Rajan and Zingales (1998), liberalization may improve domestic firms' access to external finance, which might in turn increase the rate at which firms import capital goods.
} 
productivity depends on reasonable differences in views about the elasticity of substitution that have yet to be resolved in the literature.

\section{Conclusion}

In the process of debating the impact of trade on wages, international economists pay relatively little attention to the impact of trade in capital. Debating the costs and benefits of capital market liberalization on economic growth, macro and financial economists largely ignore the implications of increased capital market integration for wages. Yet labor income typically accounts for about two-thirds of GDP. Almost two decades after the advent of capital account liberalization in the developing world, our paper provides the first systematic analysis of the impact of liberalization on the level of real wages.

Increased capital market integration in the 1980s and 1990s sharply reduced the cost of capital for manufacturing firms in emerging economies. In response to the fall in their cost of capital, these firms installed new machinery, much of which was imported from abroad, and may have embodied substantial technological progress. The combination of capital deepening and technological progress drove up the productivity of workers in the manufacturing sector. Accordingly, the demand for those workers increased, along with their real wage. ${ }^{26}$

While the focus of this paper is on the level of real wages, our findings also provide important clues about the rise in wage inequality in developing countries documented by Goldberg and Pavcnik (2007). If the liberalization-induced increase in wages was evenly distributed across skilled and unskilled workers in the manufacturing sector, then no increase in the skill premium would have occurred. However, two observations suggest that the increase in manufacturing sector wages was probably concentrated among highly skilled workers. First, countries' imports of machinery and equipment rise substantially in the aftermath of capital account liberalizations and firms that import machinery and equipment generally employ a larger share of high-skilled workers than firms that do not import such capital (Harrison and Hanson, 1999). Second, work that is characterized as unskilled from a developed country's perspective

\footnotetext{
${ }^{26}$ Cragg and Epelbaum (1996) and Behrman, Birdsall, and Szekely (2000) make a similar argument for Latin America.
} 
may be skilled-labor intensive when compared with typical domestic production activities in a developing country (Feenstra and Hanson, 1997, 2003).

While it seems plausible to consider that capital market liberalization contributed to increased wage inequality in developing countries during the 1980s and 1990s, it is no more than a conjecture because the economic model we employ makes no distinction between skilled and unskilled workers. Moving from conjecture to testable prediction would require a model with skilled labor, unskilled labor, and capital as three distinct factors of production. In a three-factor model, capital deepening could exacerbate wage inequality through a form of skill-biased technological change if capital is more substitutable for unskilled workers and more complementary to skilled workers. However, since we do not use such a model, and our data do not provide information about the skill composition of the labor force, we cannot test this prediction.

Be that as it may, the bottom line of this paper is that increased capital market integration has raised the average standard of living for a significant fraction of the workforce in developing countries. If labor is mobile across sectors, then over time we would expect the productivitydriven wage gains in manufacturing to translate into higher incomes for workers elsewhere in the economy. The extent to which the labor market in these countries functions well enough to allow workers to respond to wage differentials across sectors is an important issue that lies beyond the scope of this paper. ${ }^{27}$ As the quality and breadth of data on labor markets in developing countries continues to improve, future work may produce more definitive conclusions.

27 See Wacziarg and Seddon Wallack (2004) for an analysis of intersectoral mobility of labor in response to trade reforms. 


\section{REFERENCES}

Aitken, Brian, Ann Harrison, and Robert Lipsey. 1996. "Wages and foreign ownership: A comparative study of Mexico, Venezuela, and the United States." Journal of International Economics, 40(3-4), 345-371.

Alfaro, Laura, and Eliza Hammel. 2007. "Capital Flows and Capital Goods." Journal of International Economics, 72(1), 128-150.

Alfaro, Laura, Sebnem Kalemli-Ozcan, and Vadym Volosovych. 2008. "Why Doesn't Capital Flow from Rich to Poor Countries? An Empirical Investigation." Review of Economics and Statistics, 90(2), 347-368.

Almeida, Rita. 2007. "The Effects of Foreign Owned Firms on the Labor Market." Journal of International Economics, 72(1), 75-96.

Ashenfelter, Orley. 1978. "Estimating the Effect of Training Programs on Earnings" Review of Economics and Statistics, 60 (1), 47-57.

Barro, Robert J., and Xavier Sala-I-Martin. 1995. Economic Growth. New York: McGraw Hill.

Behrman, Jere, Nancy Birdsall, and Miguel Szekely. 2000. "Economic Reform and Wage Differentials in Latin America." IADB Working Paper 435. Washington, DC: Inter American Development Bank.

Bekaert, Geert, Campbell Harvey, and Christian Lundblad. 2001. "Emerging Equity Markets and Economic Development.” Journal of Development Economics, 66(2), 465-504.

Bertrand, Marianne, Esther Duflo, and Sendhil Mullainathan. 2004. "How Much Should We Trust Difference in Difference Estimates?” Quarterly Journal of Economics, 119(1), 249-75.

Borjas, George, Richard B. Freeman, and Lawrence F. Katz. 1997. "How Much Do Immigration and Trade Affect Labor Market Outcomes?” Brookings Papers on Economic Activity, 1, 1-90.

Caballero, Ricardo J. 1994. "Small Sample Bias and Adjustment Costs" Review of Economics and Statistics, 76, 52-58.

Cameron, A. Colin, Jonah Gelbach, and Douglas L. Miller. 2006. "Bootstrap-Based Improvements for Inference with Clustered Errors." Working Paper 06-21, Department of Economics, University of California-Davis.

Cameron, A. Colin, Jonah Gelbach, and Douglas L. Miller. 2009. "Robust Inference with Multiway Clustering.” NBER Technical Working Paper Number 327. 
Card, David. 2009. “Immigration and Inequality.” NBER Working Paper Number 14683.

Caselli, Francesco, and Daniel Wilson. 2003. "Importing Technology." Journal of Monetary Economics, 51(1), 1-32.

Chari, Anusha, and Peter Blair Henry. 2008. "Firm-Specific Information and the Efficiency of Investment." Journal of Financial Economics, 87 (3), 636-655.

Chari, Anusha, Paige P. Ouimet, and Linda L. Tesar. 2004. "Cross Border Mergers and Acquisitions in Emerging Markets: The Stock Market Valuation of Corporate Control." EFA 2004 Maastricht Meetings Paper No. 3479.

Chirinko, Robert S. 1993. "Business Fixed Investment Spending: Modeling Strategies, Empirical Results, and Policy Implications.” Journal of Economic Literature, 31, 1875-1911.

Cline, William R. 1995. International Debt Reexamined. Washington, D.C.: Institute for International Economics.

-----. 1997. Trade and Income Distribution. Washington, D.C.: Institute for International Economics.

Coulibaly, Brahima, and Jonathan Millar. 2007. "Estimating the Long-Run User Cost Elasticity for a Small Open Economy: Evidence Using Data from South Africa." Federal Reserve Board of Governors, Finance and Economics Discussion Series, 2007-25.

Cragg, M.I., and M. Epelbaum. 1996. "Why has Wage Dispersion Grown in Mexico? Is it the Incidence of Reforms or the Growing Demand for Skills?" Journal of Development Economics, 51, 99-116.

DeLong, J. Bradford. 2004. "Should We Still Support Untrammeled International Capital Mobility? Or Are Capital Controls Less Evil than We Once Believed?" The Economists' Voice, 1.

Eaton, Jonathan, and Samuel Kortum. 1999. "International Technology Diffusion: Theory and Measurement.” International Economic Review, 40(3), 1999, 537-570.

2001a. "Technology, Trade, and Growth: A Unified Framework." European Economic Review, 45(4-6), 2001, 742-755.

-------. 2001b. “Trade in Capital Goods.” European Economic Review, 45(7), 2001, 1195-1235.

Eichengreen, Barry. 2001. "Capital Account Liberalization: What Do Cross-Country Studies Tell Us?” World Bank Economic Review, 16(3), 341-365.

Feenstra, Robert C., and Gordon. H. Hanson. 1997. "Foreign Direct Investment and Relative Wages: Evidence from Mexico's Maquiladoras." Journal of International Economics, 42(3-4), $371-93$. 
-------. 2003. "Global Production Sharing and Rising Inequality: A Survey of Trade and Wages" in Handbook of International Trade, eds. E.K. Choi, and J. Harrigan. Malden, MA: Blackwell, 146-185.

Frankel, Jeffrey A. 1994. "Introduction" in The Internationalization of Equity Markets, Jeffrey A. Frankel, ed. Chicago and London: University of Chicago Press, 1-20.

Goldberg, Pinelopi, and Nina Pavcnik. 2007. "Distributional Effects of Globalization in Developing Countries." Journal of Economic Literature, 45(1), 39-82.

Gollin, Douglas. 2002. "Getting Income Shares Right.” Journal of Political Economy, 90, 458474.

Gourinchas, Pierre Olivier, and Olivier Jeanne. 2006. "The Elusive Gains from International Financial Integration.” Review of Economic Studies, 73(3), 715-741.

Gozzi, Juan Carlos, Ross Levine, and Sergio L. Schmukler. 2010. "Patterns of International Capital Raisings.” Journal of International Economics, 80(1), 45-57.

Groningen Growth and Development Centre (GGDC). 2011. Total Economy Database. Retrieved on 10 April 2011 from http://www.ggdc.net/databases/ted.htm.

Hale, Galina, and Cheryl Long. 2008. "Did Foreign Direct Investment Put an Upward Pressure on Wages in China?" Federal Reserve Bank of San Francisco Working Paper, Number 200625 .

Harrison, Ann and Gordon Hanson. 1999. "Who Gains From Trade Reform? Some Remaining Puzzles.” Journal of Development Economics, 59(1), 125-154.

Henry, Peter Blair. 2002. “Is Disinflation Good for the Stock Market?” Journal of Finance, 57(4), 1617-1648.

-------. 2003. "Capital Account Liberalization, the Cost of Capital, and Economic Growth." American Economic Review, 93(2), 91-96.

--------. 2007. “Capital Account Liberalization: Theory, Evidence, and Speculation.” Journal of Economic Literature, 45(4), 887-935.

Karolyi, Andrew. 2004. "The Role of American Depositary Receipts in the Development of Emerging Markets." Review of Economics and Statistics, 86(3), 670-690.

Kose, Ayhan, Eswar Prasad, Kenneth Rogoff, and Shang-Jin Wei. 2006. "Financial Globalization: A Reappraisal.” NBER Working Paper No. 12484.

Krugman, Paul. 1995. "Growing World Trade: Causes and Consequences." Brookings Papers on Economic Activity, 1, 327-362. 
Lawrence, Robert Z., and Matthew Slaughter. 1993. "International Trade and American Wages in the 1980s: Giant Sucking Sound or Small Hiccup?" Brookings Papers on Economic Activity: Microeconomics, 1, 161-226.

Lawrence, Robert. 2008. Blue-Collar Blues: Is Trade to Blame for Rising US Income Inequality? Washington: Petersen Institute for International Economics.

Levine, Ross. 1997. "Financial Development and Economic Growth: Views and Agenda." Journal of Economic Literature, 35(2), 688-726.

Levine, Ross, and Sara Zervos. 1998a. "Stock Markets, Banks, and Economic Growth." American Economic Review, 88(3), 537-58.

-------. 1998b. "Capital Control Liberalization and Stock Market Development." World Development, 26(7), 1169-83.

Maddison, Angus. 1980. "Monitoring the Labour Market: A Proposal for a Comprehensive Approach in Official Statistics (Illustrated by Recent Developments in France, Germany and the U.K.)" Review of Income and Wealth, 26(2), 175-217.

Obstfeld, Maurice. 2009. "International Finance and Growth in Developing Countries: What Have We Learned?" NBER Working Paper 14691.

Organisation for Economic Co-operation and Development (OECD). 2008. OECD Benchmark Definition of Foreign Direct Investment, 4th Edition. Retrieved on 12 December 2009 from http://www.oecd.org/dataoecd/26/50/40193734.pdf.

Ottaviano, Gianmarco, and Giovanni Peri. 2008. "Immigration and Wages; Clarifying the Theory and Empirics" NBER Working Paper Number 14188.

Park, Keith, and Antoine W. Van Agtmael, 1993. The World's Emerging Stock Markets: Structure, Development, Regulations and Opportunities. Chicago: Probus Publishing Company.

Pencavel, John. 1986. "Labor Supply of Men: A Survey" in Handbook of Labor Economics, Orley Ashenfelter and Richard Layard, (eds), I, 3-102.

Petersen, Mitchell. 2009. "Estimating Standard Errors in Finance Panel Data Sets: Comparing Approaches." Review of Financial Studies, January, 22: 435-480.

Price, Margaret M. 1994. Emerging Stock Markets. New York: McGraw Hill.

Rajan, Raghuram, and Luigi Zingales. 1998. "Financial Development and Growth." American Economic Review, 88(3), 559-586.

Rodríguez, Francisco, and Daniel Ortega. 2006. “Are capital shares higher in poor countries? 
Evidence from Industrial Surveys." Wesleyan Economics Working Papers 2006-023, Department of Economics, Wesleyan University.

Rogoff, Kenneth. 1999. "International Institutions for Reducing Global Financial Instability." in Journal of Economic Perspectives, 13(4), 21-42.

Romer, Paul M. 1986. "Increasing Returns and Long-Run Growth" in Journal of Political Economy, 94, 1002-1037.

Sachs, Jeffrey, and Andrew Warner. 1995. "Economic Reform and the Process of Global Integration.” Brookings Papers on Economic Activity, 1, 1-95.

Shleifer, Andrei, and Daniel Wolfenzon. 2002. "Investor Protection and Equity Markets." Journal of Financial Economics, 66, 3-57.

Stolper, Wolfgang, and Paul Samuelson. 1941. "Protection and real wages." Review of Economic Studies, 9, 58-73.

Stulz, René M. 2005. “The Limits of Financial Globalization.” Journal of Finance, 60(4), 15951638.

Thompson, Samuel B. 2006. "Simple Formulas for Standard Errors that Cluster by Both Firm and Time." Unpublished working paper, Harvard University.

Wacziarg, Romain, and Jessica Seddon Wallack. 2004. "Trade liberalization and Intersectoral Labor Movements.” Journal of International Economics, 64 (3), 411-435.

Wilcoxon, Frank. 1945. "Individual Comparisons by Ranking Methods" in Biometrics Bulletin, $1(6), 80-83$.

Wilson, Ian M. 1992. The Wilson Directory of Emerging Market Funds. Saskatoon: Wilson Emerging Market Funds Research. 
Figure 1. ReAL Wage Growth Rises IN the WaKe of CAPITAL AcCount LIBERALIZATIONS.

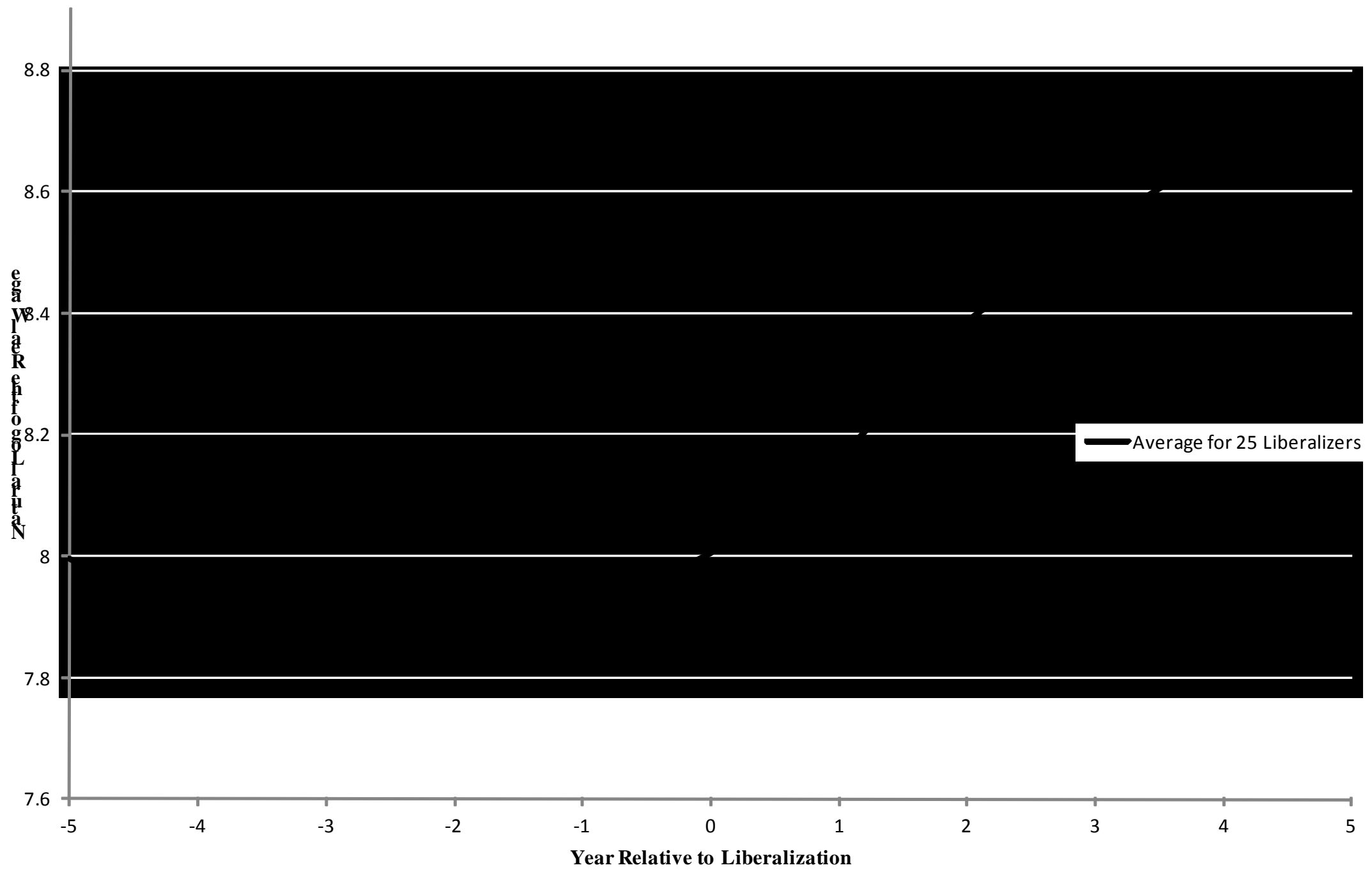


Figure 2. Productivity Rises in the Wake of CAPital AcCount Liberalizations.

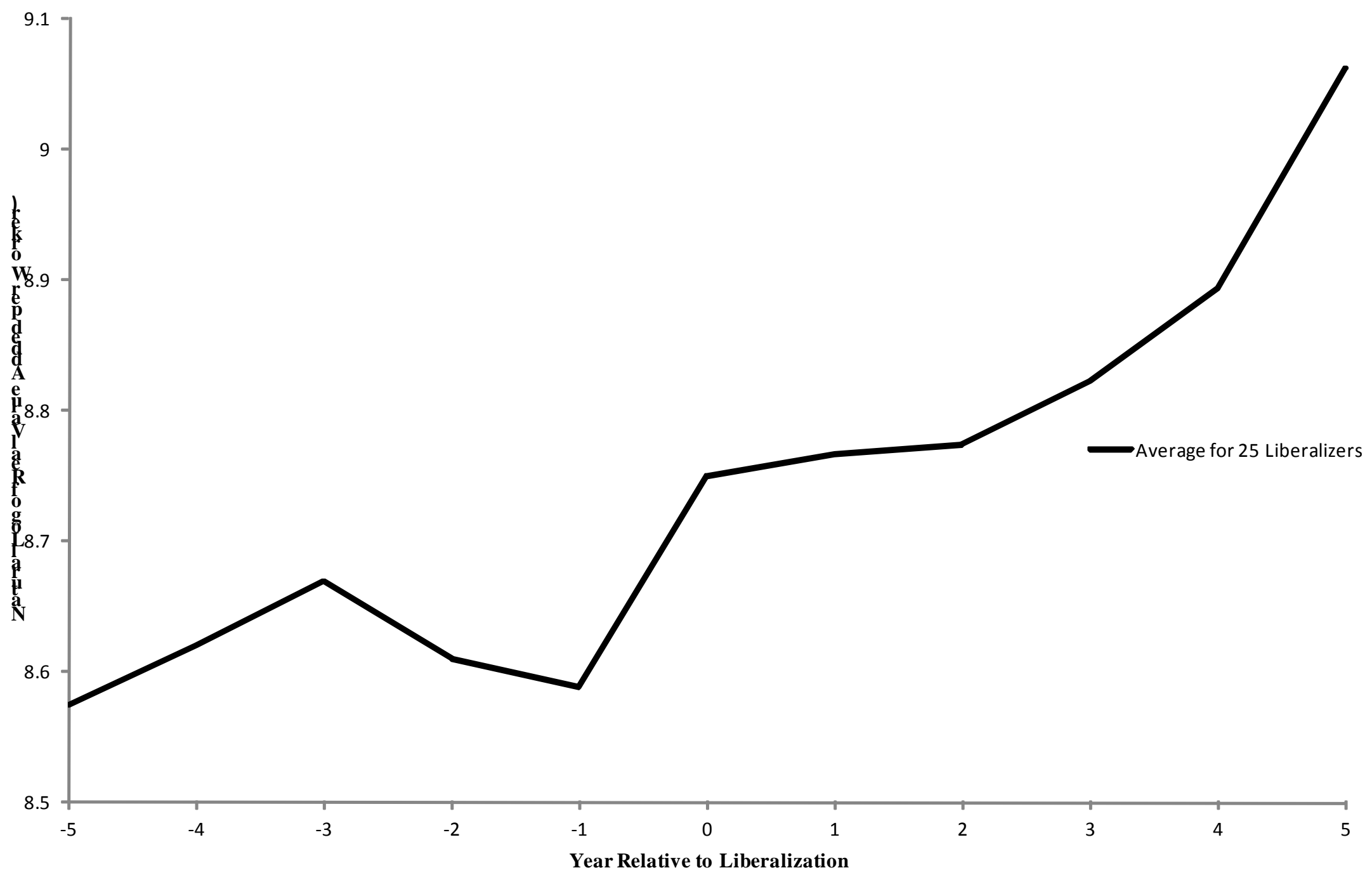

37 
Figure 3. Hypothetical ImpaCt of LiberalizATION ON the Cost of CAPITAL, InVESTMENT AND THE REAL WAGE.

PANel A: The Cost OF CAPITAL
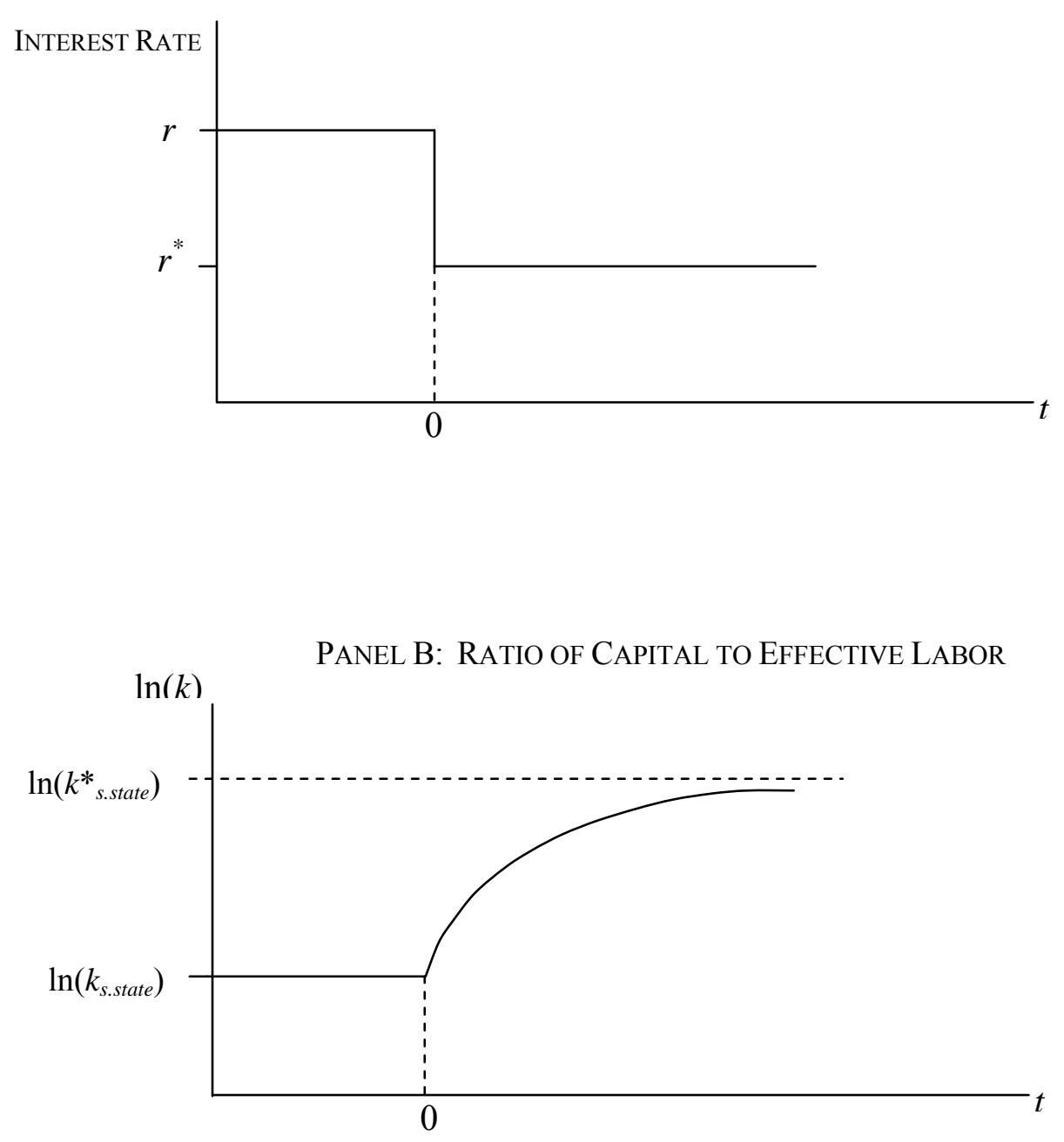

PANel C: ReAL WAGE

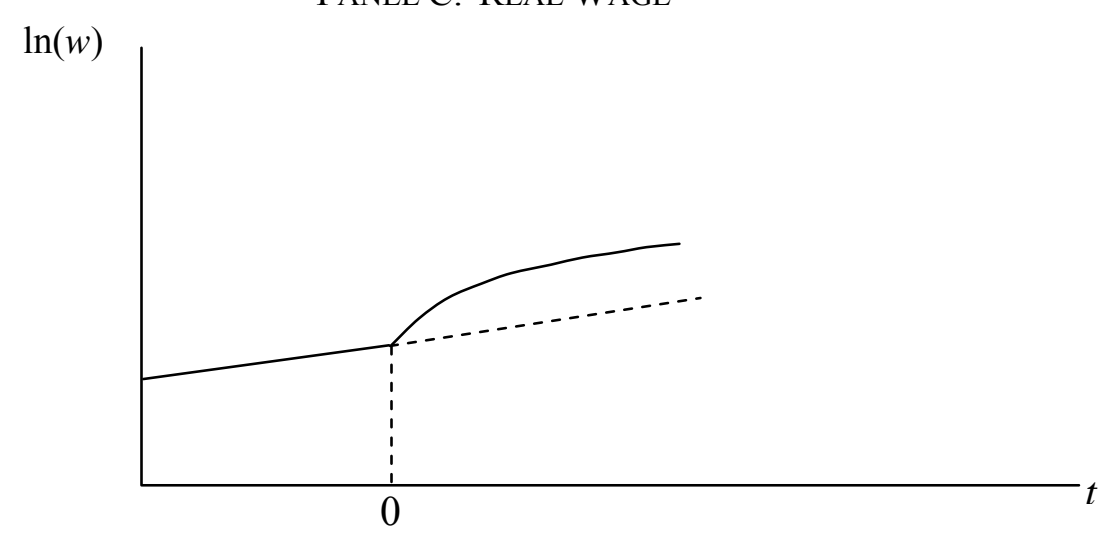


Figure 4. EQUity INFLOWS SOARED WHEN EMERGING ECONOMIES LIBERALIZED THEIR STOCK MARKETS.

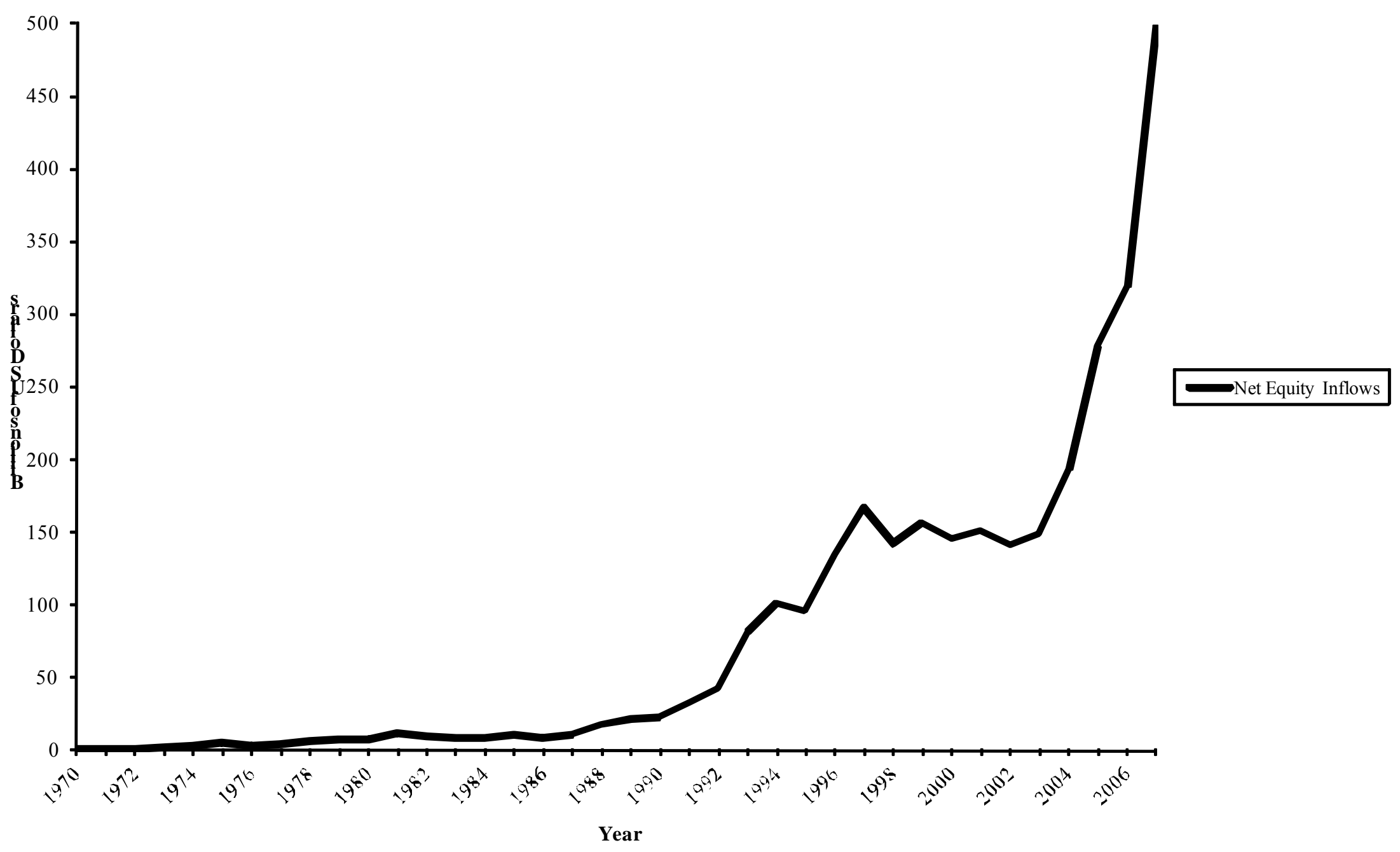


Figure 5. The Average Number of Hours Worked DoES NOT RiSE WITH LiBERALIZATION.

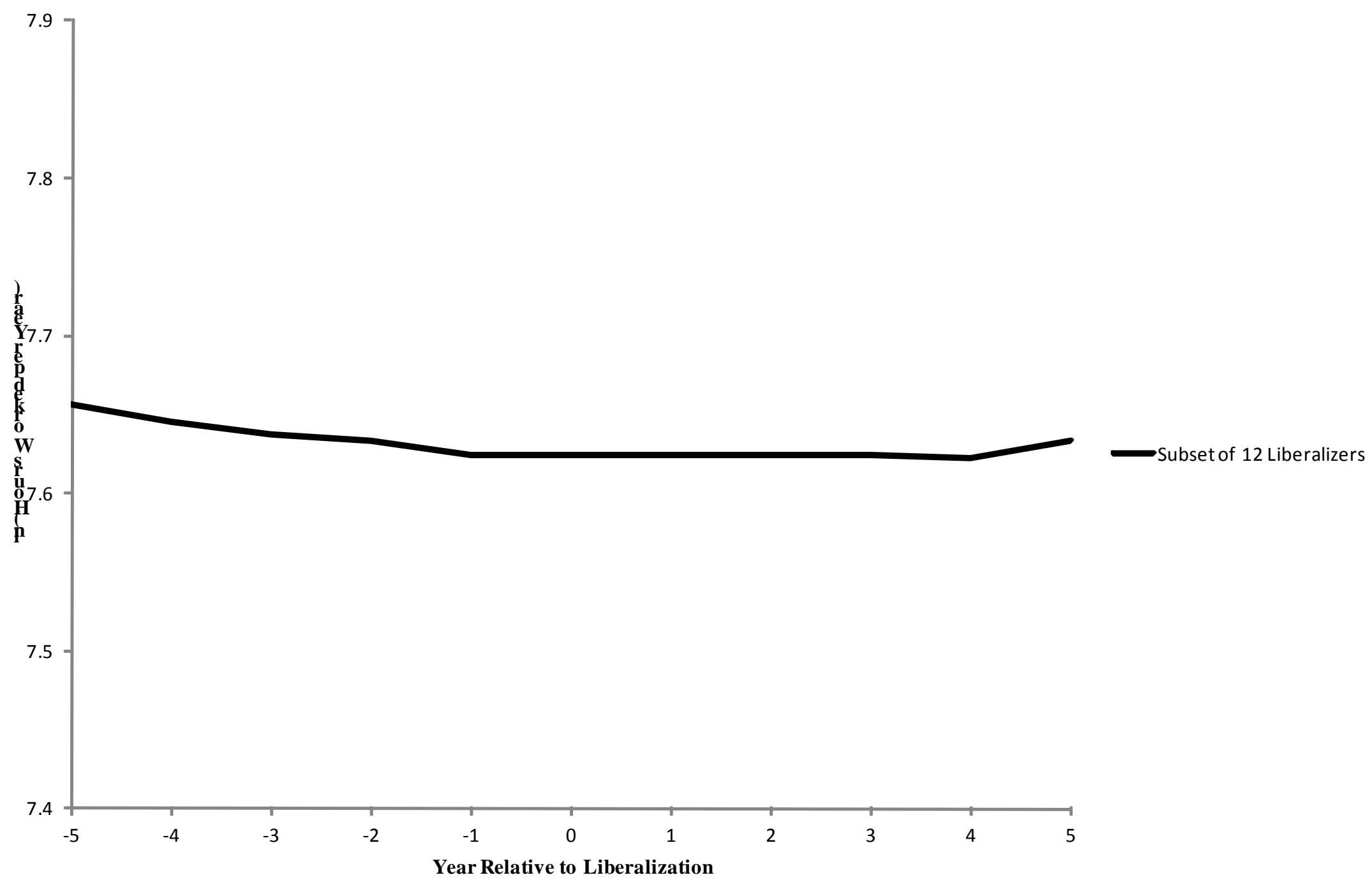


Table 1. Capital Account Liberalizations Occur Around the Same Time as Other Major Economic Reforms.

\begin{tabular}{|c|c|c|c|c|c|}
\hline Country & $\begin{array}{l}\text { Capital Account } \\
\text { Liberalization }\end{array}$ & Stabilization & Trade Liberalization & Privatization & $\begin{array}{l}\text { Brady Plan Debt } \\
\text { Relief } \\
\end{array}$ \\
\hline Brazil & Mar-88 & Jan-89 & Apr-90 & Jul-90 & Aug-92 \\
\hline Colombia & Dec-91 & NA & 1986 & 1991 & NA \\
\hline Egypt & Feb-91 & Apr-91 & Apr-91 & Apr-91 & NA \\
\hline Greece & Jul-94 & Jul-89 & Apr-53 & Nov-90 & NA \\
\hline Israel & Oct-89 & Jul-85 & Feb-52 & Jan-86 & NA \\
\hline Jordan & Dec-95 & May-94 & 1965 & Jan-95 & Jun-93 \\
\hline Malaysia & May-87 & NA & 1963 & 1988 & NA \\
\hline Mexico & May-89 & May-89 & Jul-86 & Nov-88 & Sep-89 \\
\hline Morocco & Dec-92 & Jan-84 & Sep-83 & 1993 & NA \\
\hline South Africa & Mar-95 & Mar-86 & Apr-94 & Apr-94 & NA \\
\hline South Korea & Jun-87 & Jul-85 & 1968 & NA & NA \\
\hline Spain & Jan-93 & Jan-78 & Jul-59 & 1985 & NA \\
\hline Taiwan & May-86 & NA & 1963 & NA & NA \\
\hline Thailand & Sep-87 & Jun-85 & Always Open & 1988 & NA \\
\hline Turkey & Aug-89 & Jul-94 & 1989 & 1988 & NA \\
\hline Venezuela & Jan-90 & Jun-89 & May $1989 * *$ & Apr-91 & Jun-90 \\
\hline Zimbabwe & Jun-93 & Sep-92 & NA & 1994 & NA \\
\hline
\end{tabular}

Notes: The capital account liberalization dates identified in this table are the dates on which the eighteen countries in Column 1 eased restrictions prohibiting foreign ownership of domestic stocks. The liberalization dates in Column 2 are an amalgamation of those in Henry (2000), Levine and Zervos (1998b) and Bekaert and Harvey (2000). Columns 2 through 6 list the dates of major economic reforms that occurred around the same time as the capital account liberalizations. The stabilization program dates in Column 3 come from Henry (2002) and various issues of the IMF Annual Reports. Column 4 lists trade liberalization dates from 
Sachs and Warner (1995). The privatization dates in Column 5 come from the Privatization Data Base maintained by the World Bank. Finally, Column 6 lists the month and year that each country received debt relief under the Brady Plan. The debt relief dates come from Cline (1995), Lexis Nexis, and various issues of the Economist Intelligence Unit. **Venezuela reversed its trade liberalization reforms in 1993. 
TABLE 2. Summary Statistics For Real Wage Growth DuRING CAPITAL ACCOUNT LIBERALIZATION EPISODES

\begin{tabular}{|c|c|c|c|c|}
\hline \multicolumn{5}{|c|}{ Panel A } \\
\hline & (1) & (2) & (3) & (4) \\
\hline Country & $\begin{array}{c}\text { Liberalization } \\
\text { Real Wage } \\
\text { Change }\end{array}$ & $\begin{array}{c}\text { Liberalization } \\
\text { Wage Change } \\
\text { Relative to } \\
\text { Pre- } \\
\text { liberalization } \\
\text { Wages }\end{array}$ & $\begin{array}{c}\text { Liberalization } \\
\text { Wage Change } \\
\text { Relative to } \\
\text { Control } \\
\text { Group }\end{array}$ & $\begin{array}{c}\text { Difference- } \\
\text { in-Difference } \\
\text { Wage } \\
\text { Change }\end{array}$ \\
\hline Argentina & $-2.88 \%$ & $3.10 \%$ & $18.70 \%$ & $16.26 \%$ \\
\hline Brazil & $25.15 \%$ & $23.78 \%$ & $38.17 \%$ & $19.12 \%$ \\
\hline Chile & $20.18 \%$ & $6.36 \%$ & $30.98 \%$ & $1.50 \%$ \\
\hline Colombia & $9.75 \%$ & $9.25 \%$ & $22.76 \%$ & $4.37 \%$ \\
\hline Greece & $9.33 \%$ & $13.11 \%$ & $30.19 \%$ & $33.61 \%$ \\
\hline India & $13.18 \%$ & $9.79 \%$ & $23.97 \%$ & $2.32 \%$ \\
\hline Indonesia & $-4.54 \%$ & $-14.53 \%$ & $12.25 \%$ & $-2.16 \%$ \\
\hline Israel & $16.38 \%$ & $14.64 \%$ & $19.93 \%$ & $5.51 \%$ \\
\hline Jordan & $14.12 \%$ & $23.63 \%$ & $13.39 \%$ & $13.93 \%$ \\
\hline Malaysia & $2.57 \%$ & $-3.71 \%$ & $27.02 \%$ & $22.98 \%$ \\
\hline Mexico & $23.00 \%$ & $39.07 \%$ & $39.80 \%$ & $44.93 \%$ \\
\hline Morocco & $23.68 \%$ & $19.77 \%$ & $32.72 \%$ & $22.49 \%$ \\
\hline Nigeria & $-51.99 \%$ & $25.87 \%$ & $-51.68 \%$ & $0.13 \%$ \\
\hline Pakistan & $3.01 \%$ & $-10.01 \%$ & $5.54 \%$ & $-22.24 \%$ \\
\hline Philippines & $14.15 \%$ & $6.25 \%$ & $27.17 \%$ & $3.22 \%$ \\
\hline Portugal & $45.40 \%$ & $59.56 \%$ & $60.26 \%$ & $66.57 \%$ \\
\hline South Africa & $6.77 \%$ & $3.06 \%$ & $17.56 \%$ & $-4.33 \%$ \\
\hline South Korea & $49.05 \%$ & $27.45 \%$ & $69.91 \%$ & $54.30 \%$ \\
\hline Spain & $6.35 \%$ & $8.30 \%$ & $11.01 \%$ & $3.88 \%$ \\
\hline Taiwan & $42.79 \%$ & $17.19 \%$ & $57.64 \%$ & $34.13 \%$ \\
\hline Thailand & $17.16 \%$ & $-8.00 \%$ & $35.18 \%$ & $12.61 \%$ \\
\hline Turkey & $59.46 \%$ & $65.14 \%$ & $76.26 \%$ & $73.59 \%$ \\
\hline Venezuela & $-13.13 \%$ & $35.15 \%$ & $-2.35 \%$ & $17.75 \%$ \\
\hline Zimbabwe & $51.08 \%$ & $99.55 \%$ & $60.29 \%$ & $87.78 \%$ \\
\hline Mean & $15.83 \%$ & $19.74 \%$ & $28.19 \%$ & $21.35 \%$ \\
\hline
\end{tabular}


Panel B

\begin{tabular}{|c|c|c|c|c|}
\hline & $(1)$ & $(2)$ & (3) & (4) \\
\hline $\begin{array}{c}\text { Right Hand Side } \\
\text { Variable }\end{array}$ & $\begin{array}{c}\text { Liberalization } \\
\text { Real Wage } \\
\text { Change }\end{array}$ & $\begin{array}{c}\text { Liberalization } \\
\text { Wage Change } \\
\text { Relative to } \\
\text { Pre- } \\
\text { liberalization } \\
\text { Wages } \\
\end{array}$ & $\begin{array}{c}\text { Liberalization } \\
\text { Wage Change } \\
\text { Relative to } \\
\text { Control } \\
\text { Group } \\
\end{array}$ & $\begin{array}{c}\text { Difference in } \\
\text { Difference } \\
\text { Wage } \\
\text { Change }\end{array}$ \\
\hline Constant & $\begin{array}{l}0.1583 * * * \\
(0.048)\end{array}$ & $\begin{array}{l}0.1915 * * * \\
(0.051)\end{array}$ & $\begin{array}{c}0.2687 * * * \\
(0.054)\end{array}$ & $\begin{array}{l}0.2015^{* * * *} \\
(0.054)\end{array}$ \\
\hline Observations & 25 & 25 & 25 & 25 \\
\hline
\end{tabular}

Notes: Panel A shows the following summary statistics for each country. Column 1 shows the log real wage change from event year [0] to [3] for each country's liberalization episode. Column 2 presents the liberalization real wage change expressed relative to the country's mean log real wage change from [-3] to [-1]. Column 3 is the liberalization log real wage change expressed relative to the contemporaneous mean log real wage change for the control group countries between years [0] and [3]. Column 4 presents the difference-in-difference log real wage change that subtracts the different in the pre-liberalization wage change between the treatment and control groups from the quantity in column 3. In Panel B, for columns $1-4$, we test whether the mean differs significantly from zero and report a heteroscedasticity-consistent estimate of the standard error in parentheses. $(* * *),(* *),(*)$ represent $1 \%, 5 \%$ and $10 \%$ levels of significance, respectively. 
TABLE 3. ThE IMPACT OF LiBERALIZATION ON REAL WAGE GROWTH IS TEMPORARY AND

DECLINES OVER TIME.

\begin{tabular}{|c|c|c|c|c|c|c|c|}
\hline \multicolumn{8}{|c|}{ Panel A } \\
\hline & (1) & (2) & (3) & \multicolumn{2}{|c|}{ (4) } & $(5)$ & $(6)$ \\
\hline $\begin{array}{l}\text { Time } \\
\text { Window }\end{array}$ & $([-3],[-1])$ & $([0],[2])$ & $([0],[3])$ & \multicolumn{2}{|c|}{$([0],[4])$} & $([0],[5])$ & $([0],[6])$ \\
\hline Liberalize & $\begin{array}{c}-0.0237 * * \\
(0.011)\end{array}$ & $\begin{array}{c}0.0341 * * * \\
(0.013)\end{array}$ & $\begin{array}{c}0.0369 * * * \\
(0.012)\end{array}$ & \multicolumn{2}{|c|}{$\begin{array}{c}0.0314 * * * \\
(0.011)\end{array}$} & $\begin{array}{c}0.0190 * \\
(0.011)\end{array}$ & $\begin{array}{c}0.012 \\
(0.011)\end{array}$ \\
\hline Constant & $\begin{array}{c}0.0154 * * * \\
(0.01)\end{array}$ & $\begin{array}{l}0.006 \\
(0.01)\end{array}$ & $\begin{array}{l}0.004 \\
(0.01)\end{array}$ & \multicolumn{2}{|c|}{$\begin{array}{l}0.004 \\
(0.01)\end{array}$} & $\begin{array}{l}0.006 \\
(0.01)\end{array}$ & $\begin{array}{l}0.008 \\
(0.01)\end{array}$ \\
\hline $\mathrm{N}$ & 437 & 437 & 437 & \multicolumn{2}{|c|}{437} & 437 & 437 \\
\hline R-squared & 0.139 & 0.145 & 0.15 & \multicolumn{2}{|c|}{0.147} & 0.138 & 0.135 \\
\hline \multicolumn{8}{|c|}{ Panel B } \\
\hline & $(1)$ & (2) & (3) & (4) & \multicolumn{2}{|c|}{ (5) } & (6) \\
\hline & Year [0] & Year [1] & Year [2] & Year [3] & \multicolumn{2}{|c|}{ Year [4] } & Year [5] \\
\hline Liberalize & $\begin{array}{c}0.0002 \\
(0.02)\end{array}$ & $\begin{array}{c}0.0476 * * \\
(0.015)\end{array}$ & $\begin{array}{c}0.0718 * * \\
(0.021)\end{array}$ & $\begin{array}{c}0.0316 \\
(0.02)\end{array}$ & \multicolumn{2}{|c|}{$\begin{array}{r}-0.0047 \\
(0.023)\end{array}$} & $\begin{array}{l}-0.0456 \\
(0.032)\end{array}$ \\
\hline Constant & $\begin{array}{c}0.0114^{* *} \\
\quad(0.01)\end{array}$ & $\begin{array}{r}0.0064 \\
(0.01)\end{array}$ & $\begin{array}{r}0.0078 \\
(0.01)\end{array}$ & $\begin{array}{c}0.0099 * \\
(0.01)\end{array}$ & \multicolumn{2}{|c|}{$\begin{array}{c}0.0116^{* *} \\
(0.01)\end{array}$} & $\begin{array}{c}0.0134 * * * \\
(0.01)\end{array}$ \\
\hline $\mathrm{N}$ & 437 & 437 & 437 & 437 & \multicolumn{2}{|c|}{437} & 437 \\
\hline R-squared & 0.132 & 0.149 & 0.152 & 0.136 & \multicolumn{2}{|c|}{0.132} & 0.139 \\
\hline
\end{tabular}

Notes: Panel A presents coefficient estimates on the liberalization dummy over time or the time profile of the impact of liberalization on the growth rate of real wages. Panel A presents estimates of the coefficient on the liberalization dummy allowing progressively more periods after the reform (from 2 up to 6) and for the pre-liberalization period ([-3],[-1]). The left-hand side variable is the natural log of the real wage change. Panel B presents the coefficient estimates on the liberalization dummy by individual year ranging from the liberalization year [0] up to five years following the liberalization [5]. $\mathrm{N}$ is the number of observations. Robust standard errors appear in parentheses. $(* * *),(* *),(*)$ represent $1 \%, 5 \%$ and $10 \%$ levels of significance, respectively. 
TABLE 4. LIBERALIZATION TEMPORARILY INCREASES THE GROWTH RATES OF REAL WAGES \& PRODUCTIVITY.

\begin{tabular}{|c|c|c|c|c|c|c|c|}
\hline \multirow{2}{*}{$\begin{array}{l}\text { Dependent Variable } \\
\text { Time Window }\end{array}$} & \multicolumn{2}{|c|}{$\begin{array}{l}\text { Real Wage (log-difference } \\
\text { relative to control group) }\end{array}$} & \multicolumn{2}{|c|}{$\begin{array}{l}\text { Real Wage (log-difference } \\
\text { relative to control group) }\end{array}$} & \multirow{2}{*}{$\begin{array}{c}\begin{array}{c}\text { Real Wage } \\
\text { (log- }\end{array} \\
\text { difference) }\end{array}$} & \multicolumn{2}{|c|}{$\begin{array}{l}\text { Real Value-Added per } \\
\text { worker (log-difference } \\
\text { relative to control group) } \\
\end{array}$} \\
\hline & $([-3],[+3])$ & Full Sample & $([-3],[+3])$ & Full Sample & & $([-3],[+3])$ & $([-3],[+3])$ \\
\hline & $(1)$ & $(2)$ & $(3)$ & $(4)$ & $(5)$ & $(6)$ & $(7)$ \\
\hline Liberalize & $\begin{array}{c}0.0314 * * * \\
(0.011)\end{array}$ & $\begin{array}{c}0.0362 * * \\
(0.014)\end{array}$ & $\begin{array}{c}0.0394 * * \\
(0.015)\end{array}$ & $\begin{array}{l}0.0474 * * * \\
(0.015)\end{array}$ & $\begin{array}{c}0.0388 * * \\
(0.015)\end{array}$ & $\begin{array}{c}0.0972 * * * \\
(0.034)\end{array}$ & $\begin{array}{c}0.1026^{* * *} \\
(0.016)\end{array}$ \\
\hline Trade & $\begin{array}{l}0.0051 \\
(0.021)\end{array}$ & $\begin{array}{l}0.0172 \\
(0.014)\end{array}$ & $\begin{array}{l}0.0211 \\
(0.021)\end{array}$ & $\begin{array}{l}0.0197 \\
(0.015)\end{array}$ & $\begin{array}{l}0.0170 \\
(0.014)\end{array}$ & $\begin{array}{l}0.0509 \\
(0.045)\end{array}$ & $\begin{array}{c}0.0694 * * * \\
(0.024)\end{array}$ \\
\hline Stabilize & $\begin{array}{l}0.0228 \\
(0.023)\end{array}$ & $\begin{array}{c}-0.0303 \\
(0.02)\end{array}$ & $\begin{array}{l}-0.0288 \\
(0.022)\end{array}$ & $\begin{array}{l}-0.0289 \\
(0.023)\end{array}$ & $\begin{array}{l}-0.0278 \\
(0.017)\end{array}$ & $\begin{array}{l}-0.0577 \\
(0.099)\end{array}$ & $\begin{array}{l}-0.0622 \\
(0.067)\end{array}$ \\
\hline Privatize & $\begin{array}{l}0.0285 \\
(0.023)\end{array}$ & $\begin{array}{l}0.0165 \\
(0.016)\end{array}$ & $\begin{array}{l}0.0298 \\
(0.027)\end{array}$ & $\begin{array}{l}0.0100 \\
(0.016)\end{array}$ & $\begin{array}{l}0.0055 \\
(0.019)\end{array}$ & $\begin{array}{l}-0.0603 \\
(0.049)\end{array}$ & $\begin{array}{l}-0.0430 \\
(0.041)\end{array}$ \\
\hline Brady & $\begin{array}{l}0.0405 \\
(0.031)\end{array}$ & $\begin{array}{l}0.0168 \\
(0.025)\end{array}$ & $\begin{array}{c}-0.0265 * * \\
(0.012)\end{array}$ & $\begin{array}{l}-0.0226 \\
(0.025)\end{array}$ & $\begin{array}{c}0.0155 \\
(0.023)\end{array}$ & $\begin{array}{l}-0.0011 \\
(0.116)\end{array}$ & $\begin{array}{c}-0.0676 \\
(0.09)\end{array}$ \\
\hline Constant & $\begin{array}{c}0.0104 \\
(0.014)\end{array}$ & $\begin{array}{c}0.0211 * * * \\
(0.006)\end{array}$ & $\begin{array}{c}0.0196 \\
(0.016)\end{array}$ & $\begin{array}{c}0.0215^{* * *} \\
(0.008)\end{array}$ & $\begin{array}{c}0.0180 * * * \\
(0.006)\end{array}$ & $\begin{array}{c}-0.0332 \\
(0.09)\end{array}$ & $\begin{array}{r}-0.0361 \\
(0.071)\end{array}$ \\
\hline Standard Errors & $\begin{array}{l}\mathrm{Clu} \\
(\mathrm{Co}\end{array}$ & $\begin{array}{l}\text { ered } \\
\text { ntry) }\end{array}$ & $\begin{array}{r}\mathrm{Cl} \\
\text { (Count }\end{array}$ & $\begin{array}{l}\text { ered } \\
\& \text { Year) }\end{array}$ & Ro bust & $\begin{array}{c}\text { Clustered } \\
\text { (Year) }\end{array}$ & $\begin{array}{c}\text { Clustered } \\
\text { (Country \& } \\
\text { Year) }\end{array}$ \\
\hline Country Fixed Effects & Yes & Yes & No & No & Yes & Yes & No \\
\hline Year Fixed Effects & No & No & No & No & Yes & No & No \\
\hline Observations & 152 & 722 & 152 & 722 & 758 & 146 & 146 \\
\hline R-squared & 0.38 & 0.12 & 0.092 & 0.03 & 0.1730 & 0.19 & 0.07 \\
\hline
\end{tabular}

Notes: The estimation procedure is ordinary least squares. Standard errors appear in parentheses. The symbols $(* * *),(* *)$, and $(*)$ represent significance levels of $1 \%, 5 \%$, and $10 \%$, respectively. LIBERALIZE is a dummy variable that takes on the value of 1 in the year that country $i$ liberalizes (year [0]) and each of the subsequent three years ([1] [2] and [3]). TRADE, STABILIZE, PRIVATIZE, and $B R A D Y$ are dummy variables that take on the value 1 whenever a trade liberalization, inflation stabilization, privatization or Brady plan program takes place during country $i$ 's capital account liberalization episode. $([-3],[+3])$ denotes a time window of three years prior to and following the liberalization year. 
TABLE 5. LIBERALIZATION DOES NOT SIGNIFICANTLY IMPACT EMPLOYMENT.

\begin{tabular}{|c|c|c|c|c|c|c|}
\hline & (1) & (2) & (3) & (4) & (5) & (6) \\
\hline Liberalize & $\begin{array}{c}-0.015 \\
(0.021)\end{array}$ & $\begin{array}{l}-0.0141 \\
(0.022)\end{array}$ & $\begin{array}{c}-0.0154 \\
(0.021)\end{array}$ & $\begin{array}{l}-0.0189 \\
(0.023)\end{array}$ & $\begin{array}{c}-0.0061 \\
(0.02)\end{array}$ & $\begin{array}{r}-0.0106 \\
(0.021)\end{array}$ \\
\hline Trade & & $\begin{array}{l}-0.0159 \\
(0.083)\end{array}$ & & & & $\begin{array}{r}-0.0101 \\
(0.089)\end{array}$ \\
\hline Stabilize & & & $\begin{array}{c}-0.0148 \\
(0.019)\end{array}$ & & & $\begin{array}{r}0.0106 \\
(0.028)\end{array}$ \\
\hline Privatize & & & & $\begin{array}{c}0.0115 \\
(0.02)\end{array}$ & & $\begin{array}{c}0.0173 \\
(0.027)\end{array}$ \\
\hline Brady & & & & & $\begin{array}{l}-0.1201 \\
(0.079)\end{array}$ & $\begin{array}{r}-0.1260 \\
(0.087)\end{array}$ \\
\hline Constant & $\begin{array}{c}-0.0443 * * \\
(0.019)\end{array}$ & $\begin{array}{c}-0.0421 * * \\
(0.021)\end{array}$ & $\begin{array}{c}-0.0448 * * \\
(0.019)\end{array}$ & $\begin{array}{c}-0.0456^{* *} \\
(0.019)\end{array}$ & $\begin{array}{l}-0.0211 \\
(0.027)\end{array}$ & $\begin{array}{c}-0.0203 \\
(0.03)\end{array}$ \\
\hline Observations & 783 & 783 & 783 & 783 & 783 & 783 \\
\hline R-squared & 0.12 & 0.12 & 0.12 & 0.12 & 0.122 & 0.122 \\
\hline
\end{tabular}

Notes: The estimation procedure is ordinary least squares. All specifications contain year-specific and countryspecific dummy variables. Standard errors appear in parentheses. The symbols $(* * *),(* *)$, and $(*)$ represent significance levels of $1 \%, 5 \%$, and $10 \%$, respectively. For the regressions reported, the left-hand-side variable is the change in the natural log of employment over the full sample. LIBERALIZE is a dummy variable that takes on the value of 1 in the year that country $i$ liberalizes (year [0]) and each of the subsequent three years ([1] [2] and [3]). TRADE, STABILIZE, PRIVATIZE, and BRADY are dummy variables that take on the value 1 whenever a trade liberalization, inflation stabilization, privatization or Brady Plan program takes place during country i's capital account liberalization episode. 
Countries that had not liberalized as of 1997: Algeria, Bangladesh, Barbados, Benin, Burkina Faso, Cameroon, Central African Republic, Chad, Congo, Costa Rica, Cote D'Ivoire, Dominican Republic, Ecuador, El Salvador, Fiji, Gabon, Gambia, Ghana, Guatemala, Guyana, Haiti, Honduras, Iceland, Iran, Jamaica, Kenya, Kuwait, Madagascar, Malawi, Mali, Malta, Mauritius, Nepal, Nicaragua, Niger, Oman, Paraguay, Peru, Rwanda, Saudi Arabia, Senegal, Sierra Leone, Syrian Arab Republic, Togo, Trinidad and Tobago, Tunisia, Uruguay, Zambia.

Countries that liberalized before 1980: Australia, Austria, Denmark, Finland, Ireland, Norway.

Countries that liberalized between 1980 and 1997: Argentina, Brazil, Chile, Colombia, Egypt, Greece, India, Indonesia, Israel, Jordan, Malaysia, Mexico, Morocco, New Zealand, Nigeria, Pakistan, Philippines, Portugal, South Africa, Spain, Sri Lanka, Thailand, Turkey, Venezuela, Zimbabwe. 